\title{
The implementation of resistance training principles in exercise interventions for lower limb tendinopathy: A systematic review
}

Ian Burton MSc, CSCS.

Physiotherapist, Angus HSCP, NHS Tayside, Dundee, United Kingdom

Please cite as: Burton, I. (2020). The implementation of resistance training principles in exercise interventions for lower limb tendinopathy: A systematic review. SportRxiv doi: 10.31236/osf.io/8etvu

\section{ABSTRACT}

Objectives: The primary purpose of this systematic review is to examine the literature on resistance training interventions for lower limb tendinopathy to evaluate the proportion of interventions that implemented key resistance training principles (specificity, progression, overload, individualisation) and reported relevant prescription components (frequency, intensity, sets, repetitions) and reported intervention adherence.

Design: Two reviewers performed a qualitative systematic review after screening titles and abstracts based on eligibility criteria. Identified papers were obtained in 
full text, with data extracted regarding the implementation of resistance training principles. Included articles were evaluated by the Cochrane risk of bias tool, with a scoring tool out of 10 used for implementation and reporting of the 5 key principles. Scientific databases were searched in November 2020 and included Medline, CINAHL, AMED, and Sportsdiscus.

Results: 52 randomised controlled trials investigating resistance training in five different lower limb tendinopathies were included. Although most studies considered the principles of progression (92\%) and individualisation (88\%), only 19 studies (37\%) appropriately described how this progression in resistance was achieved, and only 18 studies (35\%) reported specific instruction on how individualisation was applied. Adherence was considered in 27 studies (52\%), with only 17 studies (33\%) reporting the levels of adherence. In the scoring criteria, only 5 studies (10\%) achieved a total maximum score of 10 , with 17 studies (33\%) achieving a maximum score of 8 for implementing and reporting the principles of specificity, overload, progression and individualisation.

Conclusion: There is meaningful variability and methodological concerns regarding the application and reporting of resistance training principles, particularly progression and individualisation, along with intervention adherence throughout studies. Collectively, these findings have important implications for the prescription of current resistance training interventions, including the design and implementation of future interventions for populations with lower limb tendinopathies.

\section{Introduction}

Recent evidence has highlighted the enormous global burden of musculoskeletal disorders, with approximately 1.3 billion prevalent cases and 121,300 deaths due to musculoskeletal disorders in 2017, as well as 138.7 million disability-adjusted life years (Safiri et al. 2020). Tendinopathies of the lower limb represent some of the most common musculoskeletal disorders, with a high prevalence in both the general sedentary population and athletic individuals (Minetto et al. 2020; 
Ganestam et al. 2016; Riel et al. 2019). Prevalent tendinopathies such as Achilles, patellar and plantar heel cause chronic pain, disability, functional and activity limitations and impaired quality of life (Abat et al. 2017). Despite a range of treatment options being available, exercise and particularly different forms of resistance training are most often implemented and recommended, however only moderate long-term effectiveness for improving pain and function has been demonstrated (Girgis and Duarte, 2020; Cardoso et al. 2019; Riel et al. 2019; Dimitrios 2015). Recently, the extent of heterogeneity within tendinopathy populations has been highlighted, with a host of individual factors been shown to influence risk and onset of tendinopathy, as well as outcomes to treatment such as resistance training (Steinmann et al. 2020). Therefore, the response of individuals to exercise interventions can be diverse and multifactorial, due to the interactions of a plethora of factors (Ferreira et al. 2020; Dean et al. 2017). Response to resistance training may be dependent on tendinopathy type and stage on the continuum, duration, age, individual intrinsic and extrinsic factors as well as exercise parameters such as the type, dose, duration, frequency, volume and intervention adherence (Barratt et al. 2017; Morrissey 2015). Therefore, it is plausible that applying a generic and standardised resistance training approach to a largely heterogenous tendinopathy population may reduce the full potential utility of the approach for improving outcomes in tendinopathy.

Resistance training interventions are typically based on the key core resistance training principles of specificity, overload and progression, which when applied appropriately can ensure sufficient challenge and adaptation of the human neuromuscular system (Fleck 2011; Fleck and Kraemer 2014; Haff and Triplett 2015). Although not considered a core principle of resistance training, the principle of individualisation has recently received increased attention and when exercise interventions are individually tailored, outcomes have been shown to be improved compared to standardised interventions (Jones et al. 2016; Mann et al. 2014; Borressen and Lambert 2009). Individualisation of exercise prescription may also be highly relevant in tendinopathy due to its heterogenous nature, and as such leading tendinopathy researchers and clinicians have stressed the importance of individualising exercise treatments to improve outcomes (Abat et al. 2017; Silbernagel et al. 2014). Implementing key resistance training principles can help 
to appropriately manipulate key training variables such as training load, volume and duration, which may impact on clinical outcomes (Hasani et al. 2020). Consequently, given the importance of optimising the key resistance training principles within tendinopathy treatment interventions, determining the extent to which these scientific principles are currently implemented may be considered integral for guiding further research and clinical recommendations for tendinopathy (Malliaras et al. 2015). It is essential that the scientific principles of resistance training are correctly applied and reported within interventions, in order to achieve optimal exercise dosages and stimulus, and to allow for an appropriate evaluation of their feasibility and effectiveness within tendinopathy populations. Therefore, a systematic evaluation of the individual components, principles and prescription of resistance training within the current lower limb tendinopathy literature is warranted.

Despite the plethora of systematic reviews examining the effectiveness of exercise interventions for lower limb tendinopathies, including resistance training, there have been no comprehensive reviews examining the application and reporting of key resistance training principles within interventions (Clifford et al. 2020; Van der Vlist et al. 2020; Vander Doelen et al. 2020; Lim et al. 2018; Malliaras et al. 2013; Murphy et al. 2019; Babatunde et al. 2018; Challoumas et al. 2019). It could be considered a highly important objective to determine the extent to which the key scientific training principles have been implemented due to inadequate long-term outcomes of resistance training for lower limb tendinopathies (Silbernagel 2014; Riel 2019). Despite this importance, the application of key principles has not been adequately investigated and reported in previous systematic reviews. An understanding of the current adoption of resistance training principles may present an avenue for improving the implementation of key principles appropriately, which may improve the utility of resistance training interventions and long-term outcomes for tendinopathy patients. 


\section{Objective}

The primary purpose of this systematic review was to examine the current literature on resistance training interventions for lower limb tendinopathies and evaluate the proportion of studies that implemented key resistance training principles (specificity, progression, overload, individualisation) and reported relevant prescription components (frequency, intensity, sets, repetitions) and reported adherence.

\section{METHODS}

\section{Design}

This was a qualitative systematic review with a priory eligibility criterion established and applied to the search strategy prior to conducting literature searches.

\section{Eligibility criteria}

This review considered randomised controlled trials (RCTs) only for eligibility for inclusion. To be considered for inclusion, RCTs must have investigated a primary resistance training intervention, either in isolation or combined with another treatment in adults with lower limb tendinopathy. Specific tendinopathies included patellar, Achilles, and gluteal tendinopathy, posterior tibial tendon dysfunction and plantar heel pain. Studies published in peer-reviewed journals and in English language were considered for inclusion.

\section{Data sources}


Scientific databases were searched in November 2020 and included Medline, CINAHL, AMED, Sportsdiscus. Search terms related to the included lower limb tendinopathies and resistance training were entered in different combinations as Medical Subject Heading (MESH) terms and keywords where appropriate. All terms were applied and modified specifically to each database. Manual searches of reference lists from other systematic reviews of resistance training interventions for lower limb tendinopathy were conducted to retrieve any additional articles. Databases were searched from 2000 to 2020 . The year 2000 was chosen to ensure seminal work is not missed as clinical research in this area began around this time. Including findings from studies published more than 20 years ago may not be relevant due to advances in both research methodologies and clinical practice for tendinopathy. Studies published in a language other than English were only included if a translation was available as translation services are not available to the authors.

\section{Article selection}

Two reviewers independently screened the title and abstracts of every citation found in the literature search to decide eligibility, with any disagreements resolved through discussion. Identified articles considered relevant were obtained in fulltext and independently assessed against the eligibility criteria by both reviewers. Any disagreements were resolved through discussion and consensus with an independent third reviewer if required. The search results are reported in accordance with the PRISMA guidelines and are presented in figure 1, which outlines the results of the comprehensive searches.

\section{Data extraction}

Relevant data from included studies were systematically extracted into predetermined templates under the following headings: population, tendinopathy diagnosed, sample size, outcome measures, outcomes (table 3), and details on 
resistance training principles and the training interventions used (table 4). The relevant details from each study were independently extracted and rated by both reviewers according to the definitions of each resistance training principle, as outlined in tables 1 and 2 . Appropriate inclusion and reporting of a training principle were assigned a ' $Y$ ', with 'NR' assigned if the principle was not reported in the study. If it was unclear whether a training principle was appropriately included, 'UC' was assigned to the principle. Characteristics of each training intervention according to the FITT principles of frequency, intensity, time and type of exercise, together with details on specific exercises used, prescribed repetitions and sets were also extracted. An overview of extracted details on the description of components of training interventions and their principles is provided in table 4. Each study was assigned a separate score rating for each of the key resistance training principles and adherence, based on application of the principle within the study design and for adequate reporting of the principle within the study. Appropriate application of each principle was assigned a score of 1 , and 0 was applied for inadequate description of the principle or if it was not used in the study. A total score for the resistance training principles and adherence was obtained for each study in the review, with a maximum score of 10 available per study. Details of the scoring criteria are provided in table 2.

\section{Risk of bias}

Included studies were critically appraised by two independent reviewers at study level for methodological quality in the review using the standardized Cochrane risk of bias tool on Covidence. Any disagreements that arose between the reviewers were resolved through discussion or with a third reviewer. The results of critical appraisal are reported in narrative form, and in a graph. All studies meeting the inclusion criteria, regardless of their methodological quality, underwent data extraction and synthesis and were included in the review. Seven criteria were appraised for RCTs. Item three which pertained to blinding was included but not considered highly relevant in final scoring and grading of recommendations, given that interventions could not be blinded. Therefore, a maximum high-quality score of 6 or 7 could be achieved, with all included studies scoring at least 4/7, which was considered a moderate quality score (figure 2 ). 
Table 1: Resistance training principles and training intervention criteria assessed

\begin{tabular}{|c|c|}
\hline Principle & Criteria for this review \\
\hline $\begin{array}{l}\text { Specificity: Training and desired } \\
\text { adaptations should be specific to the } \\
\text { tendinopathy and relevant to desired } \\
\text { outcomes }\end{array}$ & $\begin{array}{l}\text { Appropriate population targeted and } \\
\text { intervention designed to improve } \\
\text { primary outcome }\end{array}$ \\
\hline $\begin{array}{l}\text { Progression: to allow for continuous } \\
\text { adaptations, resistance or load must } \\
\text { be increased providing a greater stress } \\
\text { to the body }\end{array}$ & $\begin{array}{l}\text { Training intervention was stated to be } \\
\text { progressive with gradual increases in } \\
\text { frequency, sets, repetitions, resistance } \\
\text { or loading throughout intervention }\end{array}$ \\
\hline $\begin{array}{l}\text { Overload: for the intervention to } \\
\text { improve strength, greater than normal } \\
\text { stress and training volume must occur } \\
\text { above current training levels }\end{array}$ & $\begin{array}{l}\text { Interventions included baseline } \\
\text { strength testing or rationale that } \\
\text { intervention was of sufficient intensity } \\
\text { and volume relative to baseline } \\
\text { capacity }\end{array}$ \\
\hline $\begin{array}{l}\text { Individualisation: Training is tailored to } \\
\text { the individual to allow for consideration } \\
\text { of individual factors and training } \\
\text { response }\end{array}$ & $\begin{array}{l}\text { Training intervention considered } \\
\text { methods to individually tailor exercises } \\
\text { stimulus based on an individual's own } \\
\text { factors or training response }\end{array}$ \\
\hline Component of training & Description \\
\hline Frequency & How many times per week or day \\
\hline Intensity & $\begin{array}{l}\text { Measurement method: RM, \%RM, RPE, } \\
\text { pain level }\end{array}$ \\
\hline Time & Duration of session \\
\hline Sets & How many sets of each exercise \\
\hline Repetitions & $\begin{array}{l}\text { How many repetitions of each exercise } \\
\text { or target number of repetitions }\end{array}$ \\
\hline Exercise selection & $\begin{array}{l}\text { Outline and description of specific } \\
\text { exercises used in intervention }\end{array}$ \\
\hline Adherence & $\begin{array}{l}\text { Was adherence to the training } \\
\text { intervention monitored and reported? }\end{array}$ \\
\hline
\end{tabular}


Table 2: Scoring of the application and reporting of key training principles

\begin{tabular}{|c|c|c|c|}
\hline Principle/ & Description & & Score \\
\hline Specificity & $\begin{array}{l}\text { Design: have the } \\
\text { authors designed the } \\
\text { intervention to achieve } \\
\text { desired outcomes? } 1 / 10\end{array}$ & $\begin{array}{l}\text { Reporting: have the } \\
\text { authors adequately } \\
\text { described the } \\
\text { intervention specificity? } \\
1 / 10\end{array}$ & $2 / 10$ \\
\hline Overload & $\begin{array}{l}\text { Design: have the } \\
\text { authors appropriately } \\
\text { manipulated training } \\
\text { variables to achieve } \\
\text { desired outcomes? } 1 / 10\end{array}$ & $\begin{array}{l}\text { Reporting: have the } \\
\text { authors adequately } \\
\text { described the } \\
\text { intervention training } \\
\text { variables? } 1 / 10\end{array}$ & $2 / 10$ \\
\hline Progression & $\begin{array}{l}\text { Design: have the } \\
\text { authors appropriately } \\
\text { manipulated training } \\
\text { variables to adequately } \\
\text { progress the } \\
\text { intervention? } 1 / 10\end{array}$ & $\begin{array}{l}\text { Reporting: have the } \\
\text { authors adequately } \\
\text { described how } \\
\text { intervention progression } \\
\text { was achieved and } \\
\text { assured? } 1 / 10\end{array}$ & $2 / 10$ \\
\hline Individualisation & $\begin{array}{l}\text { Design: have the } \\
\text { authors appropriately } \\
\text { manipulated training } \\
\text { variables to adequately } \\
\text { individually tailor the } \\
\text { intervention? } 1 / 10\end{array}$ & $\begin{array}{l}\text { Reporting: have the } \\
\text { authors adequately } \\
\text { described how } \\
\text { individually tailoring the } \\
\text { intervention was } \\
\text { achieved and assured? } \\
1 / 10\end{array}$ & $2 / 10$ \\
\hline Adherence & $\begin{array}{l}\text { Design: have the } \\
\text { authors appropriately } \\
\text { designed and described } \\
\text { methods for monitoring } \\
\text { adherence? } 1 / 10\end{array}$ & $\begin{array}{l}\text { Reporting: have the } \\
\text { authors adequately } \\
\text { reported individual } \\
\text { adherence to training } \\
\text { and training dose } \\
\text { achieved? } 1 / 10\end{array}$ & $2 / 10$ \\
\hline
\end{tabular}


Figure 1: PRISMA study flow diagram
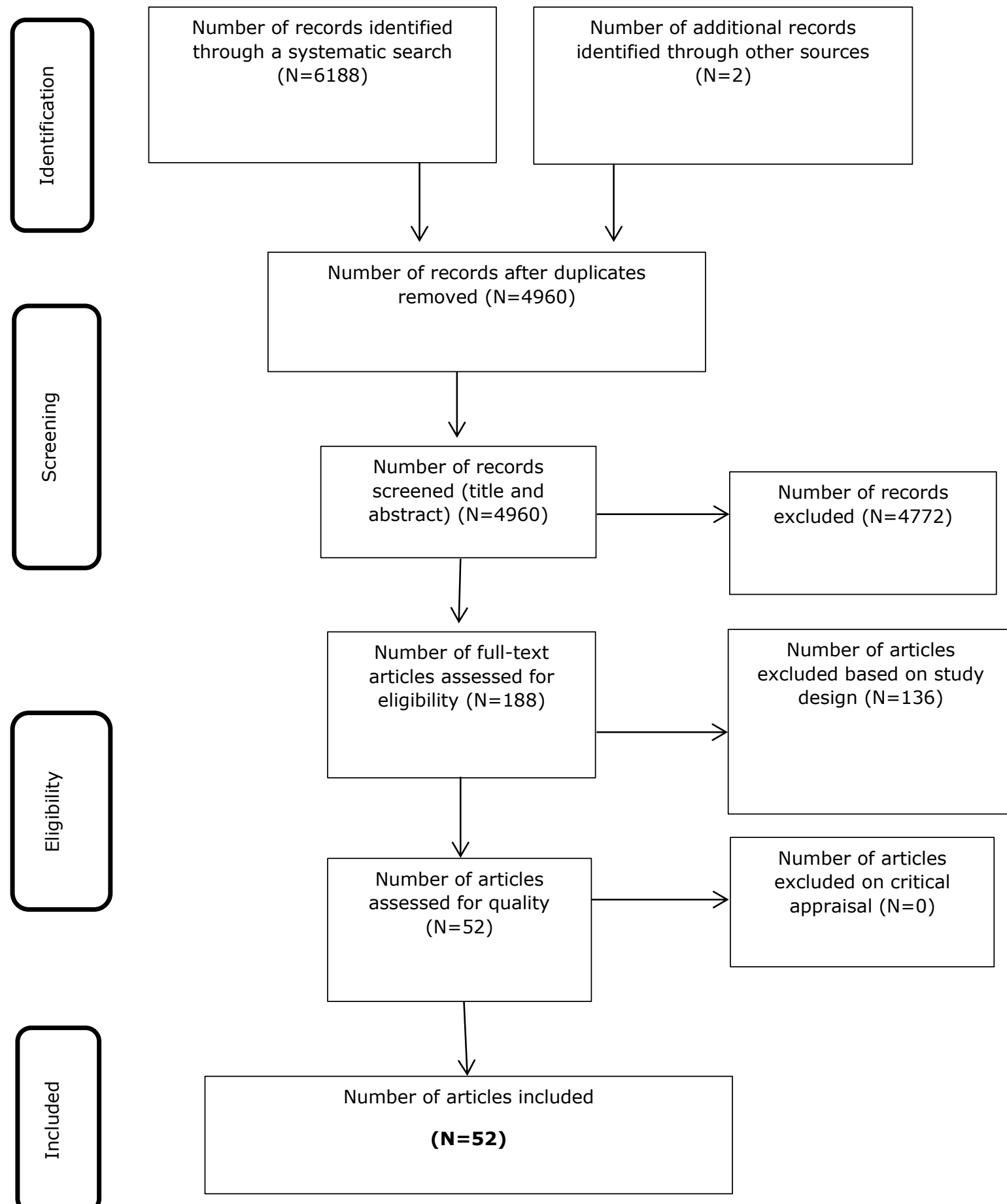

From: Moher D, Liberati A, Tetzlaff J, Altman DG, The PRISMA Group (2009). Preferred Reporting Atems for Systematic Reviews and Meta-Analyses: The PRISMA Statement. PLoS Med 6(6): e1000097. doi:10.1371/journal.pmed100009

Figure 2: Risk of bias summary 


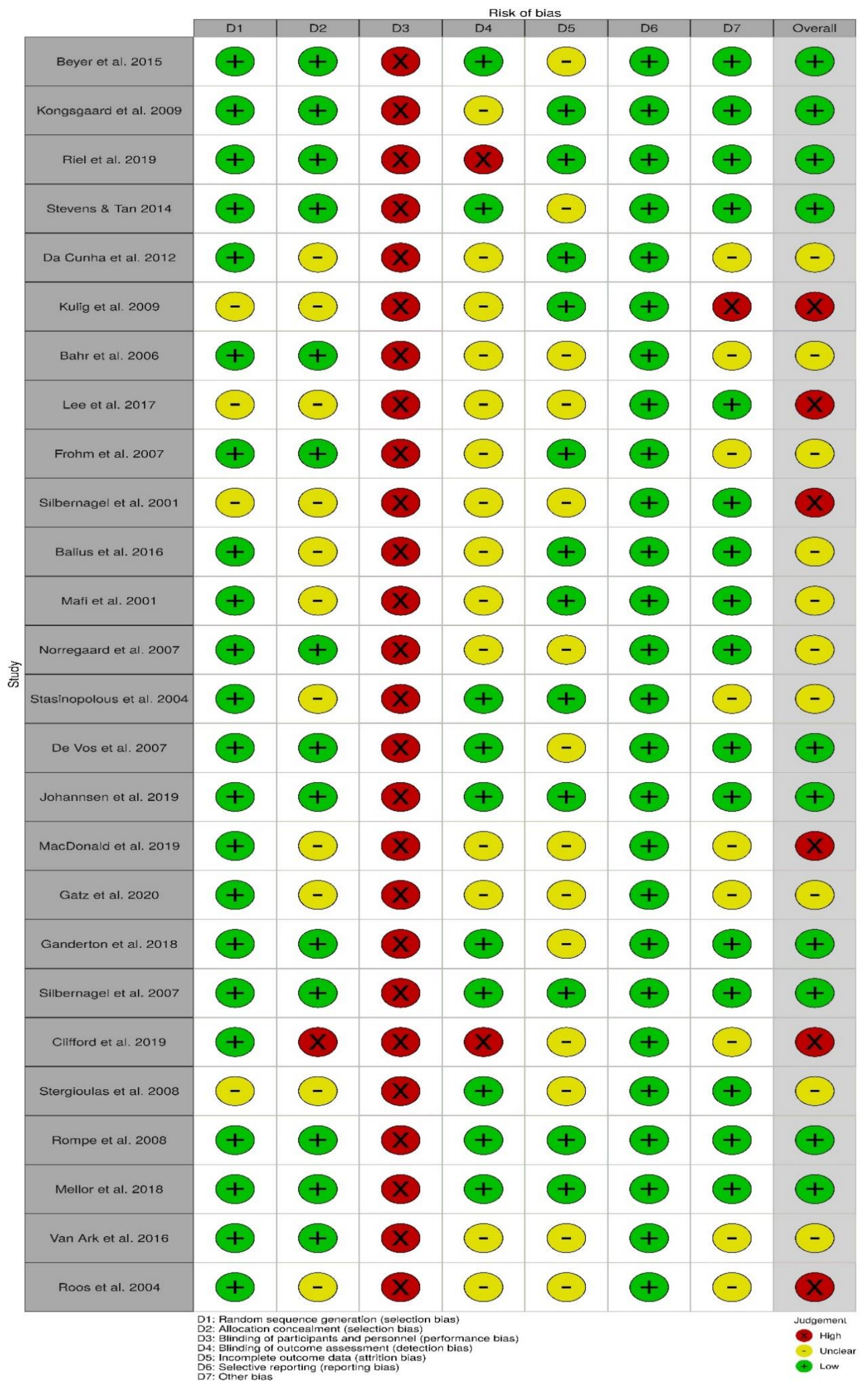




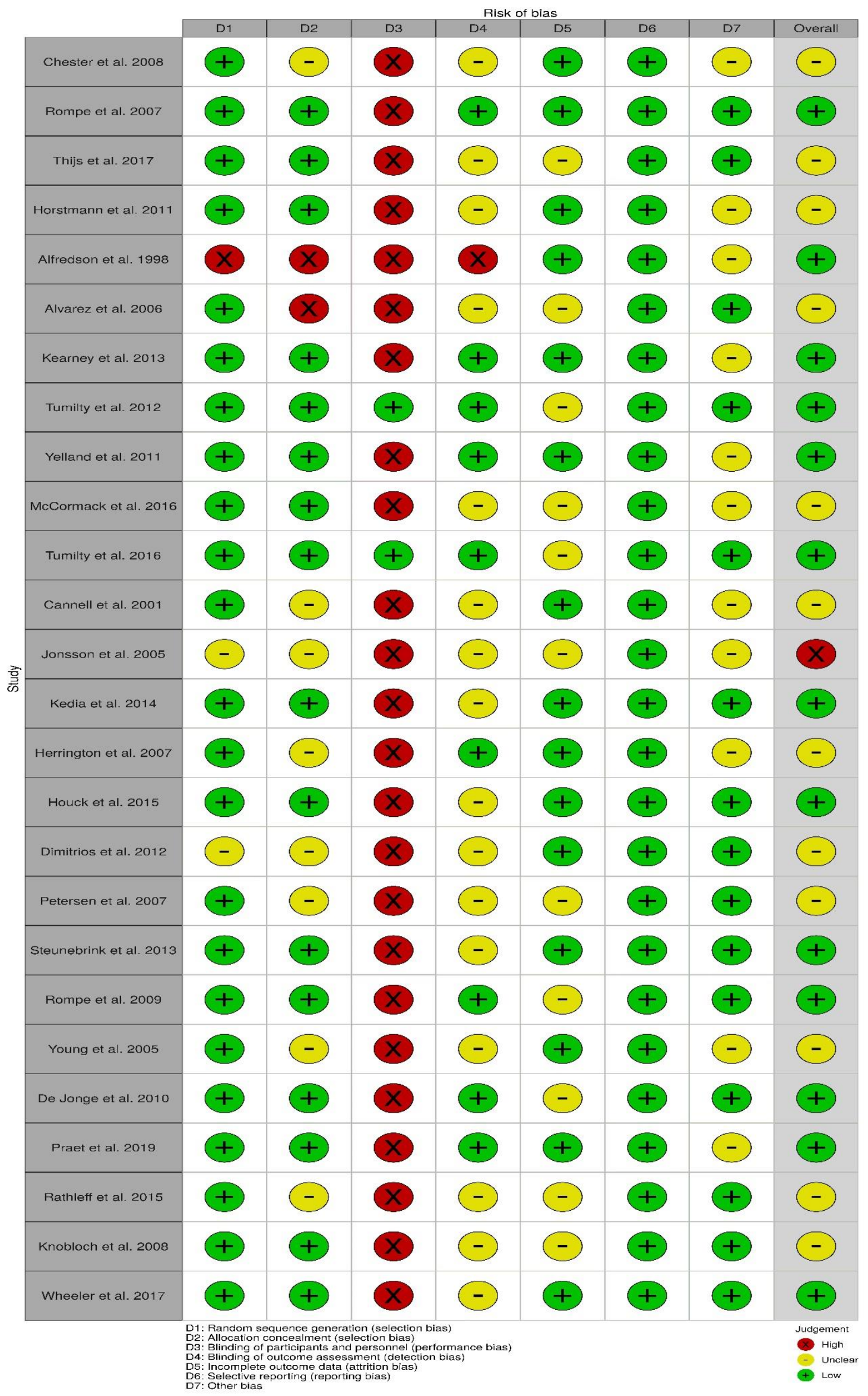




\section{Figure 3: Risk of bias graph}

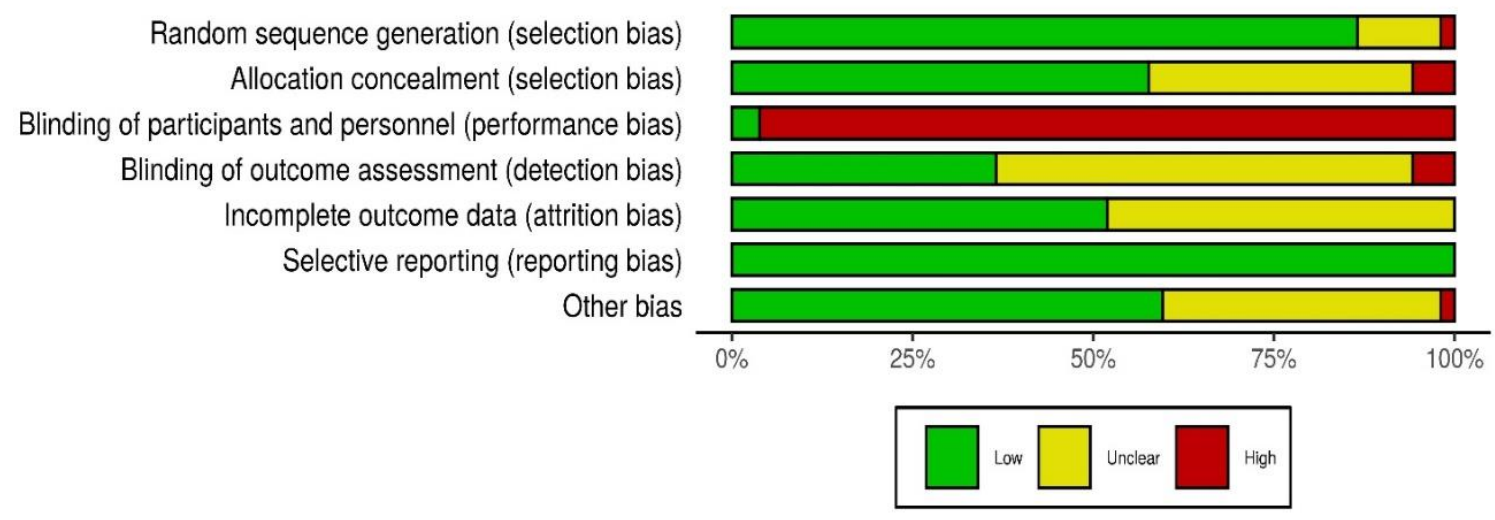

\section{Data synthesis}

The results from extraction are presented in a narrative synthesis and a summary of findings was tabulated (table 3 ) and included study characteristics, sample size, duration and outcomes together with a summary of the key training principles. The application of training components such as specific exercises, repetitions, sets and intensity is included in table 4 . The total number of studies that applied each training principle and reported intervention components was calculated into percentages based on the proportion of studies reporting a principle relative to the total number of included studies.

\section{RESULTS}

\section{Study characteristics}

An outline of the characteristics of included studies, such as intervention groups, sample size and outcomes are presented in table 3, with resistance training principles presented in table 4. A total of 6188 records were identified in the comprehensive literature search, with 188 selected for full-text review (figure 1 ). A total of 52 RCTs involving 2487 participants met the review inclusion criteria, 
with 136 studies being excluded due to wrong study design, mainly not being RCTs. Achilles tendinopathy was the most common tendinopathy investigated (26 studies), followed by patellar (16), plantar heel (4), gluteal (3), and tibialis posterior (3). All studies investigated a resistance training intervention, with most doing so in isolation, while 4 studies investigated resistance training combined with another intervention, either corticosteroid injection or orthoses. Eccentric resistance training (40 studies) was the most common resistance training type investigated, with concentric (3), isometric (3), isotonic (3) heavy slow resistance (7) and combined or general training approaches (4) also investigated. The duration of training interventions ranged from 4 to 26 weeks, with 44 studies (85\%) using a 12-week intervention. All studies adopted outcome measures which assessed pain and function outcomes of the interventions, with other measures including quality of life and tendon structure through ultrasonography. Pain was measured by VAS scales in 26 studies, and NRS in 3 studies. The VIS-A was used to measure function in 18 studies, VISA-P in 10 studies and the FFI in 5 studies. Cochrane risk of bias scores ranged from 1-6, with no studies achieving a maximum score of 7 . This was largely since resistance training interventions cannot be blinded, therefore all studies had high risk of bias for this criterion. Therefore, if a score of 6 was considered the maximum score, only 7 of 52 studies achieved this score, highlighting the high risk of bias throughout many included studies.

\section{Application of key principles}

An overview of the application of key resistance training principles within included studies is presented in table 4 . All studies (100\%) appropriately implemented the principle of specificity by targeting the resistance training to the pathological tendon with the aim of improving pain and function. The principle of overload was appropriately applied in 48/52 studies (92\%), in the form of progressively increasing resistance throughout the intervention. The principle of progression was implemented in 48/52 studies (92\%), however only 19 studies (37\%) appropriately described how this progression in resistance was achieved and with what load, most commonly with small increases in external weight. Increased 
resistance was applied by using a progressively loaded backpack in 31 studies $(60 \%)$, with 5 studies (10\%) reporting using weight machines, and 4 studies using resistance bands (8\%). Incremental increases in resistance ranged from $0.9-5 \mathrm{~kg}$, with $5 \mathrm{~kg}$ being the most common as reported in 12 studies (23\%). The principle of individualisation through individually tailoring training was applied in 46/52 studies (88\%), with 39 studies tailoring training based on pain response, four on exercise technique, two on as much volume as possible per session and one study used a BORG scale to tailor intensity. Of the studies that considered individualisation, only 18 studies (35\%) reported specific instruction on how this was applied, such as by following pain scales to a certain level before adjusting resistance. Adherence was considered in 27 studies (52\%), most commonly in the form of an exercise adherence diary. However, only 17 studies (33\%) reported the levels of adherence to the prescribed training intervention. In the scoring criteria, a maximum score of 8 was possible for application and reporting of resistance training principles only, and a total score of 10 with adherence included. Only 5 studies (10\%) achieved a total maximum score of 10, with 17 studies (33\%) achieving a maximum score of 8 for implementing and reporting the principles of specificity, overload, progression and individualisation.

\section{Reporting of resistance training components}

All but one study failed to report the frequency of training sessions (98\%). Frequency ranged from 2 to 7 days per week, and 2 to 14 sessions per week. All but two studies (96\%) failed to report the intensity of the prescribed training intervention. Intensity was prescribed either using a percentage of 1 repetition maximum (RM) or most commonly as a target RM for a session, such as 10-15 RM. Although the duration of the entire intervention was reported in all studies $(100 \%)$, the duration of each session was only reported in 7 studies (13\%). All, but two studies (96\%) reported the number of sets and repetitions of exercise. Sets ranged from 1-12, with one study including as many sets as possible (Riel et al. 2019), and repetitions per set ranged from 3-30, with one study including as many repetitions as possible (Stevens and Tan 2014). All studies reported the specific exercises used, with eccentric or isotonic heel raises being implemented 
in 33 studies (63\%), with 13 studies using eccentric decline squats (25\%). The most reported resistance training prescription throughout the interventions was the parameters of the 'Alfredson' protocol, with 25 studies (48\%) using the original protocol or slight modifications from it. The parameters of the Alfredson protocol include training twice per day, seven days per week, with 6 sets of 15 repetitions, totalling 180 repetitions per day, progressed with increased resistance by adding weight to a backpack as able. The protocol involves two variations of a standing heel raise exercise performed on a step, one performed with the knee straight to target the gastrocnemius and the other with the knee flexed to target the soleus muscles (Alfredson 1998).

\section{Discussion}

The primary purpose of this systematic review was to examine the current literature on resistance training interventions for lower limb tendinopathies and evaluate the proportion of studies that implemented key resistance training principles (specificity, progression, overload, individualisation) and reported relevant prescription components (frequency, intensity, sets, repetitions) and reported adherence. A total of 52 RCTs investigating resistance training in five different lower limb tendinopathies were included. The principles of specificity, overload, progression and individualisation were applied and reported to varying degrees throughout studies, along with consideration of exercise adherence. Although most studies considered the principles of progression (92\%) and individualisation (88\%), only 19 studies (37\%) appropriately described how this progression in resistance was achieved, and only 18 studies (35\%) reported specific instruction on how individualisation was applied. Adherence was considered in 27 studies (52\%), with only 17 studies (33\%) reporting the levels of adherence to the prescribed training intervention, which raises significant concerns regarding the levels of exercise dosage achieved within studies. In the scoring criteria, only 5 studies (10\%) achieved a total maximum score of 10 , with 17 studies (33\%) achieving a maximum score of 8 for implementing and reporting the principles of specificity, overload, progression and individualisation. There is therefore meaningful variability and methodological concerns regarding the 
application and reporting of resistance training principles, particularly progression and individualisation, along with intervention adherence throughout studies. Collectively, these findings have important implications for the prescription of current resistance training interventions, including the design and implementation of future interventions for populations with lower limb tendinopathies.

Since the publication of the Alfredson eccentric protocol for Achilles tendinopathy in 1998, eccentric resistance training has become the dominant conservative intervention strategy for lower limb tendinopathies over the last two decades (Malliaras et al. 2013). The Alfredson protocol has also been modified for patellar tendinopathy in several studies, in the form of an eccentric decline squat protocol (Visnes et al. 2007; Young et al. 2005). Although eccentric training has positive effects in treating tendinopathies, there is currently no strong evidence to suggest that decreasing or eliminating concentric actions from the stretch-shortening cycle is appropriate when treating chronic tendinopathies (Couppé et al. 2015; Malliaras et. 2013). However, eccentric only training has shown better results when compared with concentric only, for Achilles (Mafi et al. 2001), and patellar tendinopathy (Jonsson and Alfredson 2005). Systematic reviews have evaluated the evidence for eccentric resistance training, concluding that high-quality evidence is lacking despite positive clinical outcomes in lower limb tendinopathies (Mendonca et al. 2020; Girgis et al. 2020; Murphy et al. 2019: Lim and Wong, 2018). Despite Alfredson's initial high success rate with an athletic cohort, it is apparent from the evidence that not all patients have positive clinical outcomes from isolated eccentric training. Sayana et al. (2007) found that $45 \%$ of patients were considered to have failed treatment with eccentric training based on pain and function outcomes, indicating that it may not be suitable for all patients.

More recently, Heavy Slow Resistance Training (HSRT) with heavy-load concentric-eccentric contractions, has become more widespread in research and clinical practice (Couppe et al. 2015). This method was first successfully implemented in patellar tendinopathy (Kongsgaard et al. 2009) and later investigated with positive outcomes in Achilles tendinopathy (Beyer et al. 2015) and Plantar heel pain (PHP) (Rathleff et al. 2015) based on the same loading 
principles and volume progression. Whereas the Alfredson eccentric protocol stipulates a strict protocol of 180 repetitions daily, HSRT adheres more to scientific training principles, such as progressive increases in load and volume and increased rest periods. Recent evidence suggests that HSRT may have superior clinical outcomes compared to isolated eccentric training interventions and leads to greater patient satisfaction in treating lower limb tendinopathies (Murphy et al. 2019; Beyer et al. 2015; Kongsgaard et al. 2009). Despite this, evidence suggests that even HSRT protocols do not reach intended dosage levels and may require better loading and progression methods and a more individualised approach rather than a standardised protocol (Riel et al. 2019).

The finding from this review that almost half of studies (48\%) adopted the parameters of the Alfredson protocol, which involves training twice per day, seven days per week, with 6 sets of 15 repetitions, totalling 180 repetitions per day, is particularly concerning. Training twice per day with such a high volume does not follow current scientific resistance training recommendations, to achieve optimal exercise dosage, recovery, tendon and physiological adaptations required to improve clinical outcomes. The overload principle speaks to the necessity to stress biological tissues beyond their current thresholds to increase tolerance to subsequent stresses and avoid future injuries. Greater load tolerance can be achieved by training at higher loads, which also has positive effects on remodeling of the degenerated tendon (Kulig 2009). However, the Alfredson protocol for example involves training twice daily for 12 weeks, meaning it is unlikely high loads are being achieved. It is reccommended that no more than 3 high-intensity training sessions should be undertaken within a week in the recovering tendon, to allow adequate recovery and collagen synthesis (Malliaras et al. 2015; Magnussen et al. 2009). Adequate rest periods are required in training protocols for tendon adaptation in relation to anabolic and catabolic processes involved in tendon remodelling (Waugh 2018). Resistance training for longer than 12-weeks may also be necessary, in order to gain sufficient adaptation and positive results for lower limb tendinopathies (Sussmilch-Leitch et al. 2012). The dosage (e.g., number of repetitions, days per week and duration of a contraction) and type of exercise are important characteristics of an exercise program, with loads as high as $80 \%$ of 1 repetition maximum (RM) having been used for isometric ( $80 \% 1 \mathrm{RM})$ and isotonic 
exercises (80\% 8RM) (Van Ark et al. 2016). Beneficial effects from rehabilitation for tendons require high load per repetition. Furthermore, a high percentage of RM in leg extension exercises has been shown to improve muscle strength and neural activation. However the precise mechanism of effect, optimal dosage and loading strategy has not yet been determined and further research is required (Van Ark et al. 2016).

There is currently little consensus regarding which variables might influence the outcome of training, including whether training should be painful, home- versus clinic-based training, the speed of the exercise, training duration, and progression methods (Rompe et al. 2009). Large randomized controlled trials that consider these parameters and include blinded assessors and extended follow-up periods are warranted. Resistance training at a high intensity level of training, with gradual increases in loading, are required to create positive effects on both the muscle and tendon. Although the importance of mechanical loading through exercise in patients with tendinopathy is well established, the optimal exercise protocol contents and loading dosages require further investigation and may include aspects of motor control, proprioception, strength, malalignment, flexibility, kinetic chain and plyometric strength (Silbernagel 2007). The effects of different loading strategies need to be investigated in tendinopathy before they can be recommended in clinical practice, and findings in one type of tendinopathy may not necessarily be generalisable to others (Riel 2018). As previous research on lower limb tendinopathies has not found superiority of one specific resistance training type, the long-term effects of different loading programs in tendinopathy remain to be investigated (Riel 2018).

As recognised by Purdam et al. (2004) there is a question of whether most of the published studies are offering strength training, or may they be better described as active stretching with relative low intensity eccentric actions (Abat et al. 2017). It seems that published works on eccentric protocols do not offer true strength training and it might be that only HSRT develops the minimum level of load and tension to identify them as strength training based on scientific training principles. Recent evidence suggests that an intensity threshold above $70 \%$ of maximum is 
required to cause adaptations in tendon properties, including mechanical, material and morphological tendon changes (Arampatzis et al. 2020; Bohm et al. 2015). However, with the high repetition volume and inadequate loading in current protocols, it is unlikely this intensity is being achieved, which may be related to poor outcomes. Performing very slow repetitions (often 6-8 seconds) at a high repetition volume, may also lead to reduced intensity. Perhaps a better approach may be to perform less repetitions at a higher load with increased sets while maintaining the slow tempo implemented in HSRT, such as the approach known as 'cluster training' which could help maintain sufficient intensity and volume (Davies et al. 2020). In conjunction with decreased repetitions and increased loading intensity, autoregulation or self-selection of within-session load may also account better for the principle of individualisation and allow for better individual outcomes, by tailoring the training load to an individual's response (Mann et al. 2010, Helms et al. 2018; Rauch et al. 2020). Two studies included in this review (Riel et al. 2019; Stevens and Tan 2014), found that allowing patients to selfselect or autoregulate their training load was no less effective than following a standardised protocol, suggesting that autoregulation may provide a method for individually tailoring training loads to account for individual factors.

\section{Limitations}

The purpose of this systematic review was not to determine outcomes or effectiveness of resistance training interventions in lower limb tendinopathies, rather to report on the application of resistance training principles and adherence of interventions. Determining the proportion of previous studies that have implemented and reported key resistance training principles is a critical step in advancing the knowledge and application of resistance training as treatment in tendinopathy, as outcomes of current interventions have inadequate long-term outcomes. While the authors believe the findings present meaningful implications for future training interventions in tendinopathy, the review has several limitations. The review is unable to present any meaningful estimation of the effectiveness or dose response of resistance training on clinical outcomes such as pain and function in lower limb tendinopathies. Although there have been previous 
systematic reviews investigating effectiveness, conclusions are often limited and inconclusive, due to the significant heterogeneity in methodological approaches in resistance training interventions for tendinopathies. This includes inconsistencies in the application and reporting of key resistance training principles and levels of adherence to the interventions, preventing any meaningful and accurate conclusions on outcomes. Another limitation of current RCTs on resistance training is the lack of blinding in studies, which introduces potential bias, as evidenced in this review. Although blinding may be difficult to implement in resistance training interventions, blinded allocation may help minimise the potential for bias in studies.

The importance of determining if the application of resistance training principles impacts on improved outcomes for tendinopathy patients is an essential requirement. As future RCTs addressing the methodological limitations identified in this review and implementing and applying the correct scientific principles of resistance training emerge in the literature, future systematic reviews will be in a better position and more justified in using methods to determine true effectiveness on clinical outcomes with meta-analysis techniques. Most studies in this review were conducted on Achilles and patellar tendinopathy (42/52), highlighting the paucity of resistance training studies conducted on other lower limb tendinopathies to date, despite progressive resistance training being widely recognised as the gold standard treatment for lower limb tendinopathies. Therefore, the generalisability of the review findings across all lower limb tendinopathies is limited. Further research on resistance training in other lower limb tendinopathies is warranted, and its emergence would allow for expansion of the resistance training recommendations highlighted in this review.

\section{Conclusion}

This review has highlighted the meaningful variability and methodological diversity that exists across studies which have implemented resistance training interventions as treatment for lower limb tendinopathies. Although the principles 
of specificity and overload are adequately described and reported in resistance training studies, there is significant methodological shortcomings when it comes to the application and reporting of progression and individualisation principles, along with inadequate implementation and reporting of intervention adherence. Although the components of resistance training prescription are generally well reported throughout studies, the extent to which the modification of load and volume are modified to allow adequate overload and progression are poorly reported in current studies. Many studies also fail to prescribe resistance training within recommended scientific guidelines, with almost half of the studies adopting a twice daily eccentric training protocol, which does not allow for basic components of scientific training, such as recovery and progressive overload. Although many studies have shown positive clinical outcomes of various types of resistance training for lower limb tendinopathies, such as improved short-term pain and function, long-term outcomes may be considered inadequate, with up to half of patients being symptomatic at one-year follow up in several studies. This indicates that better resistance training interventions are warranted, with improvement of the implementation of resistance training principles, following scientific recommendations, being a potential avenue for improving outcomes. However, until the application of scientific resistance training principles is consistently reached in the tendinopathy literature, proper scientific appraisal and determining effectiveness through meta-analysis techniques cannot appropriately and conclusively be achieved. Future research evaluating the effects of resistance training on clinical outcomes for tendinopathies that is scientifically designed with accurate reporting of intervention adherence is urgently warranted to better elucidate the optimal treatment approach for this burdensome condition which has a significant global morbidity. 


\section{References}

1. Abat F, Alfredson H, Cucchiarini M, Madry H, Marmotti A, Mouton C, et al. Current trends in tendinopathy: Consensus of the ESSKA basic science committee. part I: Biology, biomechanics, anatomy and an exercise-based approach. J Exp Orthop. 2017 Dec;4(1):18,017-0092-6. Epub 2017 May 30.

2. Alfredson $H$, Pietila $T$, Jonsson $P$, Lorentzon R. Heavy-load eccentric calf muscle training for the treatment of chronic achilles tendinosis. Am J Sports Med. 1998 May-Jun;26(3):360-6.

3. Alvarez RG, Marini A, Schmitt C, Saltzman CL. Stage I and II posterior tibial tendon dysfunction treated by a structured nonoperative management protocol: An orthosis and exercise program. Foot Ankle Int. 2006 Jan;27(1):2-8.

4. Arampatzis A, Mersmann F, Bohm S. Individualized muscle-tendon assessment and training. Front Physiol. 2020 Jun 26;11:723.

5. Babatunde OO, Legha A, Littlewood C, Chesterton LS, Thomas MJ, Menz HB, et al. Comparative effectiveness of treatment options for plantar heel pain: $A$ systematic review with network meta-analysis. $\mathrm{Br}$ J Sports Med. 2019 $02 ; 53(3): 182-94$.

6. Bahr R, Fossan B, Loken S, Engebretsen L. Surgical treatment compared with eccentric training for patellar tendinopathy (jumper's knee). A randomized, controlled trial. J Bone Joint Surg Am. 2006 Aug;88(8):1689-98.

7. Balius R, Alvarez G, Baro F, Jimenez F, Pedret C, Costa E, et al. A 3-arm randomized trial for achilles tendinopathy: Eccentric training, eccentric training plus a dietary supplement containing mucopolysaccharides, or passive stretching plus a dietary supplement containing mucopolysaccharides. Curr Ther Res Clin Exp. 2016 Nov 18;78:1-7.

8. Barratt PA, Brookes N, Newson A. Conservative treatments for greater trochanteric pain syndrome: A systematic review. $\mathrm{Br}$ J Sports Med. 2017 Jan;51(2):97-104. 
9. Beyer R, Kongsgaard M, Hougs Kjaer B, Ohlenschlaeger T, Kjaer M, Magnusson SP. Heavy slow resistance versus eccentric training as treatment for achilles tendinopathy: A randomized controlled trial. Am J Sports Med. 2015 Jul;43(7):1704-11.

10. Bohm S, Mersmann F, Arampatzis A. Human tendon adaptation in response to mechanical loading: A systematic review and meta-analysis of exercise intervention studies on healthy adults. Sports Med Open. 2015 Dec;1(1):7,0150009-9. Epub 2015 Mar 27.

11. Borresen J, Lambert MI. The quantification of training load, the training response and the effect on performance. Sports Med. 2009;39(9):779-95.

12. Cannell LJ, Taunton JE, Clement DB, Smith C, Khan KM. A randomised clinical trial of the efficacy of drop squats or leg extension/leg curl exercises to treat clinically diagnosed jumper's knee in athletes: Pilot study. Br J Sports Med. 2001 Feb;35(1):60-4.

13. Cardoso TB, Pizzari T, Kinsella R, Hope D, Cook JL. Current trends in tendinopathy management. Best Pract Res Clin Rheumatol. 2019 Feb;33(1):12240.

14. Challoumas D, Clifford C, Kirwan P, Millar NL. How does surgery compare to sham surgery or physiotherapy as a treatment for tendinopathy? A systematic review of randomised trials. BMJ Open Sport Exerc Med. 2019 Apr $24 ; 5(1): e 000528$.

15. Chester R, Costa ML, Shepstone L, Cooper A, Donell ST. Eccentric calf muscle training compared with therapeutic ultrasound for chronic achilles tendon pain--a pilot study. Man Ther. 2008 Dec;13(6):484-91.

16. Clifford C, Challoumas D, Paul L, Syme G, Millar NL. Effectiveness of isometric exercise in the management of tendinopathy: A systematic review and metaanalysis of randomised trials. BMJ Open Sport Exerc Med. 2020 Aug 4;6(1):e000760. 
17. Clifford C, Paul L, Syme G, Millar NL. Isometric versus isotonic exercise for greater trochanteric pain syndrome: A randomised controlled pilot study. BMJ Open Sport Exerc Med. 2019 Sep 21;5(1):e000558.

18. Couppe C, Svensson RB, Silbernagel KG, Langberg H, Magnusson SP. Eccentric or concentric exercises for the treatment of tendinopathies? J Orthop Sports Phys Ther. 2015 Nov;45(11):853-63.

19. Davies TB, Halaki M, Orr R, Helms ER, Hackett DA. Changes in bench press velocity and power after 8 weeks of high-load cluster- or traditional-set structures. J Strength Cond Res. 2020 Oct;34(10):2734-42.

20. de Jonge $S$, de Vos RJ, Van Schie HT, Verhaar JA, Weir A, Tol JL. One-year follow-up of a randomised controlled trial on added splinting to eccentric exercises in chronic midportion achilles tendinopathy. Br J Sports Med. 2010 Jul;44(9):6737.

21. de Vos RJ, Weir A, Visser RJ, de Winter T, Tol JL. The additional value of a night splint to eccentric exercises in chronic midportion achilles tendinopathy: $A$ randomised controlled trial. Br J Sports Med. 2007 Jul;41(7):e5.

22. Dean BJF, Dakin SG, Millar NL, Carr AJ. Review: Emerging concepts in the pathogenesis of tendinopathy. Surgeon. 2017 Dec;15(6):349-54.

23. Dimitrios S. Exercise for tendinopathy. World J Methodol. 2015 Jun $26 ; 5(2): 51-4$.

24. Dimitrios S, Pantelis M, Kalliopi S. Comparing the effects of eccentric training with eccentric training and static stretching exercises in the treatment of patellar tendinopathy. A controlled clinical trial. Clin Rehabil. 2012 May;26(5):423-30.

25. Ferreira VMLM, Oliveira RR, Nazareno TS, Freitas LV, Mendonca LD. Interaction of foot and hip factors identifies achilles tendinopathy occurrence in recreational runners. Phys Ther Sport. 2020 Sep;45:111-9.

26. Fleck SJ. Non-linear periodization for general fitness \& athletes. J Hum Kinet. 2011 Sep;29A:41-5. 
27. Frohm A, Saartok T, Halvorsen K, Renstrom P. Eccentric treatment for patellar tendinopathy: A prospective randomised short-term pilot study of two rehabilitation protocols. $\mathrm{Br}$ J Sports Med. 2007 Jul;41(7):e7.

28. Ganderton C, Semciw A, Cook J, Moreira E, Pizzari T. Gluteal loading versus sham exercises to improve pain and dysfunction in postmenopausal women with greater trochanteric pain syndrome: A randomized controlled trial. J Womens Health (Larchmt). 2018 Jun;27(6):815-29.

29. Ganestam A, Kallemose T, Troelsen A, Barfod KW. Increasing incidence of acute achilles tendon rupture and a noticeable decline in surgical treatment from 1994 to 2013. A nationwide registry study of 33,160 patients. Knee Surg Sports Traumatol Arthrosc. 2016 Dec;24(12):3730-7.

30. Gatz M, Betsch $M$, Dirrichs $T$, Schrading S, Tingart $M$, Michalik $R$, et al. Eccentric and isometric exercises in achilles tendinopathy evaluated by the VISAA score and shear wave elastography. Sports Health. 2020 Jul/Aug;12(4):373-81.

31. Girgis B, Duarte JA. Physical therapy for tendinopathy: An umbrella review of systematic reviews and meta-analyses. Phys Ther Sport. 2020 Aug 11;46:30-46.

32. Hasani F, Haines TP, Munteanu SE, Vicenzino B, Malliaras P. Efficacy of different load intensity and time-under-tension calf loading protocols for achilles tendinopathy (the LOADIT trial): Protocol for a randomised pilot study. Pilot Feasibility Stud. 2020 Jul 13;6:99,020-00639-5. eCollection 2020.

33. Helms ER, Cross MR, Brown SR, Storey A, Cronin J, Zourdos MC. Rating of perceived exertion as a method of volume autoregulation within a periodized program. J Strength Cond Res. 2018 Jun;32(6):1627-36.

34. HORSTMANN T, JUD HM, FRÖHLICH V, MÜNDERMANN A, GRAU S. Whole-body vibration versus eccentric training or a wait-and-see approach for chronic achilles tendinopathy: A randomized clinical trial. Journal of Orthopaedic \& Sports Physical Therapy. 2013 11;43(11):794-803. 
35. Houck J, Neville C, Tome J, Flemister A. Randomized controlled trial comparing orthosis augmented by either stretching or stretching and strengthening for stage II tibialis posterior tendon dysfunction. Foot Ankle Int. 2015 Sep;36(9):1006-16.

36. Johannsen FE, Herzog RB, Malmgaard-Clausen NM, Hoegberget-Kalisz M, Magnusson SP, Kjaer M. Corticosteroid injection is the best treatment in plantar fasciitis if combined with controlled training. Knee Surg Sports Traumatol Arthrosc. 2019 Jan;27(1):5-12.

37. Jones N, Kiely J, Suraci B, Collins DJ, de Lorenzo D, Pickering C, et al. A genetic-based algorithm for personalized resistance training. Biol Sport. 2016 Jun;33(2):117-26.

38. Jonsson $\mathrm{P}$, Alfredson $\mathrm{H}$. Superior results with eccentric compared to concentric quadriceps training in patients with jumper's knee: A prospective randomised study. Br J Sports Med. 2005 Nov;39(11):847-50.

39. Kearney RS, Parsons N, Costa ML. Achilles tendinopathy management: A pilot randomised controlled trial comparing platelet-richplasma injection with an eccentric loading programme. Bone Joint Res. 2013 Oct 17;2(10):227-32.

40. Kedia M, Williams M, Jain L, Barron M, Bird N, Blackwell B, et al. The effects of conventional physical therapy and eccentric strengthening for insertional achilles tendinopathy. International Journal of Sports Physical Therapy. 2014 $08 ; 9(4): 488-97$.

41. Knobloch K, Schreibmueller L, Longo UG, Vogt PM. Eccentric exercises for the management of tendinopathy of the main body of the achilles tendon with or without the AirHeel brace. A randomized controlled trial. A: Effects on pain and microcirculation. Disabil Rehabil. 2008;30(20-22):1685-91.

42. Kongsgaard $M$, Kovanen $V$, Aagaard $P$, Doessing $S$, Hansen $P$, Laursen $A H$, et al. Corticosteroid injections, eccentric decline squat training and heavy slow resistance training in patellar tendinopathy. Scand J Med Sci Sports. 2009 Dec;19(6): 790-802. 
43. Kulig K, Reischl SF, Pomrantz AB, Burnfield JM, Mais-Requejo S, Thordarson $D B$, et al. Nonsurgical management of posterior tibial tendon dysfunction with orthoses and resistive exercise: A randomized controlled trial. Phys Ther. 2009 Jan;89(1):26-37.

44. Lee WC, Ng GY, Zhang ZJ, Malliaras P, Masci L, Fu SN. Changes on tendon stiffness and clinical outcomes in athletes are associated with patellar tendinopathy after eccentric exercise. Clin J Sport Med. 2020 Jan;30(1):25-32.

45. Lim HY, Wong SH. Effects of isometric, eccentric, or heavy slow resistance exercises on pain and function in individuals with patellar tendinopathy: $A$ systematic review. Physiother Res Int. 2018 Oct;23(4):e1721.

46. Mafi N, Lorentzon R, Alfredson $H$. Superior short-term results with eccentric calf muscle training compared to concentric training in a randomized prospective multicenter study on patients with chronic achilles tendinosis. Knee Surg Sports Traumatol Arthrosc. 2001;9(1):42-7.

47. Magnussen RA, Dunn WR, Thomson AB. Nonoperative treatment of midportion achilles tendinopathy: A systematic review. Clin J Sport Med. 2009 Jan;19(1):5464.

48. Malliaras $\mathrm{P}$, Barton $\mathrm{CJ}$, Reeves ND, Langberg $\mathrm{H}$. Achilles and patellar tendinopathy loading programmes : A systematic review comparing clinical outcomes and identifying potential mechanisms for effectiveness. Sports Med. 2013 Apr;43(4):267-86.

49. Malliaras P, Cook J, Purdam C, Rio E. Patellar tendinopathy: Clinical diagnosis, load management, and advice for challenging case presentations. J Orthop Sports Phys Ther. 2015 Nov;45(11):887-98.

50. Mann JB, Thyfault JP, Ivey PA, Sayers SP. The effect of autoregulatory progressive resistance exercise vs. linear periodization on strength improvement in college athletes. J Strength Cond Res. 2010 Jul;24(7):1718-23. 
51. Mann TN, Lamberts RP, Lambert MI. High responders and low responders: Factors associated with individual variation in response to standardized training. Sports Med. 2014 Aug;44(8):1113-24.

52. McCormack JR, Underwood FB, Slaven EJ, Cappaert TA. Eccentric exercise versus eccentric exercise and soft tissue treatment (astym) in the management of insertional achilles tendinopathy. Sports Health. 2016 May/Jun;8(3):230-7.

53. Mellor R, Bennell K, Grimaldi A, Nicolson P, Kasza J, Hodges P, et al. Education plus exercise versus corticosteroid injection use versus a wait and see approach on global outcome and pain from gluteal tendinopathy: Prospective, single blinded, randomised clinical trial. Br J Sports Med. 2018 Nov;52(22):1464-72.

54. Mendonca LM, Leite HR, Zwerver J, Henschke N, Branco G, Oliveira VC. How strong is the evidence that conservative treatment reduces pain and improves function in individuals with patellar tendinopathy? A systematic review of randomised controlled trials including GRADE recommendations. Br J Sports Med. 2020 Jan;54(2):87-93.

55. Minetto MA, Giannini A, McConnell R, Busso C, Torre G, Massazza G. Common musculoskeletal disorders in the elderly: The star triad. J Clin Med. $2020 \mathrm{Apr}$ 23;9(4):10.3390/jcm9041216.

56. Morrissey D. Guidelines and pathways for clinical practice in tendinopathy: Their role and development. J Orthop Sports Phys Ther. 2015 Nov;45(11):81922.

57. Murphy MC, Travers MJ, Chivers P, Debenham JR, Docking SI, Rio EK, et al. Efficacy of heavy eccentric calf training for treating mid-portion achilles tendinopathy: A systematic review and meta-analysis. $\mathrm{Br}$ J Sports Med. 2019 Sep;53(17):1070-7.

58. Norregaard J, Larsen CC, Bieler T, Langberg H. Eccentric exercise in treatment of achilles tendinopathy. Scand J Med Sci Sports. 2007 Apr;17(2):133-8.

59. Petersen W, Welp R, Rosenbaum D. Chronic achilles tendinopathy: A prospective randomized study comparing the therapeutic effect of eccentric 
training, the AirHeel brace, and a combination of both. Am J Sports Med. 2007 Oct;35(10):1659-67.

60. Praet SFE, Purdam CR, Welvaert M, Vlahovich N, Lovell G, Burke LM, et al. Oral supplementation of specific collagen peptides combined with calfstrengthening exercises enhances function and reduces pain in achilles tendinopathy patients. Nutrients. 2019 Jan 2;11(1):10.3390/nu11010076.

61. Purdam CR, Jonsson $P$, Alfredson $H$, Lorentzon $R$, Cook JL, Khan KM. A pilot study of the eccentric decline squat in the management of painful chronic patellar tendinopathy. Br J Sports Med. 2004 Aug;38(4):395-7.

62. Rathleff MS, Molgaard CM, Fredberg U, Kaalund S, Andersen KB, Jensen TT, et al. High-load strength training improves outcome in patients with plantar fasciitis: A randomized controlled trial with 12-month follow-up. Scand J Med Sci Sports. 2015 Jun;25(3):e292-300.

63. Rauch JT, Ugrinowitsch C, Barakat CI, Alvarez MR, Brummert DL, Aube DW, et al. Auto-regulated exercise selection training regimen produces small increases in lean body mass and maximal strength adaptations in strength-trained individuals. J Strength Cond Res. 2020 Apr;34(4):1133-40.

64. Riel H, Jensen MB, Olesen JL, Vicenzino B, Rathleff MS. Self-dosed and predetermined progressive heavy-slow resistance training have similar effects in people with plantar fasciopathy: A randomised trial. J Physiother. 2019 Jul;65(3):144-51.

65. Riel H, Lindstrom CF, Rathleff MS, Jensen MB, Olesen JL. Prevalence and incidence rate of lower-extremity tendinopathies in a danish general practice: A registry-based study. BMC Musculoskelet Disord. 2019 May 22;20(1):239,0192629-6.

66. Riel H, Olesen JL, Jensen MB, Vicenzino B, Rathleff MS. Heavy-slow resistance training in addition to an ultrasound-guided corticosteroid injection for individuals with plantar fasciopathy: A feasibility study. Pilot Feasibility Stud. 2019 Aug 24;5:105,019-0489-3. eCollection 2019. 
67. Riel H, Vicenzino B, Jensen MB, Olesen JL, Holden S, Rathleff MS. The effect of isometric exercise on pain in individuals with plantar fasciopathy: A randomized crossover trial. Scand J Med Sci Sports. 2018 Sep 11.

68. Rompe JD, Furia J, Maffulli N. Eccentric loading versus eccentric loading plus shock-wave treatment for midportion achilles tendinopathy: A randomized controlled trial. Am J Sports Med. 2009 Mar;37(3):463-70.

69. Rompe JD, Furia J, Maffulli N. Eccentric loading compared with shock wave treatment for chronic insertional achilles tendinopathy. A randomized, controlled trial. J Bone Joint Surg Am. 2008 Jan;90(1):52-61.

70. Rompe JD, Nafe B, Furia JP, Maffulli N. Eccentric loading, shock-wave treatment, or a wait-and-see policy for tendinopathy of the main body of tendo achillis: A randomized controlled trial. Am J Sports Med. 2007 Mar;35(3):374-83.

71. Roos EM, Engstrom M, Lagerquist A, Soderberg B. Clinical improvement after 6 weeks of eccentric exercise in patients with mid-portion achilles tendinopathy - a randomized trial with 1-year follow-up. Scand J Med Sci Sports. 2004 Oct; 14(5):286-95.

72. Safiri S, Kolahi AA, Cross M, Carson-Chahhoud K, Almasi-Hashiani A, Kaufman J, et al. Global, regional, and national burden of other musculoskeletal disorders 1990-2017: Results from the global burden of disease study 2017. Rheumatology (Oxford). 2020 Aug 25.

73. Sayana MK, Maffulli N. Eccentric calf muscle training in non-athletic patients with achilles tendinopathy. J Sci Med Sport. 2007 Feb;10(1):52-8.

74. Silbernagel KG. Does one size fit all when it comes to exercise treatment for achilles tendinopathy? J Orthop Sports Phys Ther. 2014 Feb;44(2):42-4.

75. Silbernagel KG, Thomee R, Eriksson BI, Karlsson J. Continued sports activity, using a pain-monitoring model, during rehabilitation in patients with achilles tendinopathy: A randomized controlled study. Am J Sports Med. 2007 Jun;35(6):897-906. 
76. Silbernagel KG, Thomee $R$, Thomee $P$, Karlsson J. Eccentric overload training for patients with chronic achilles tendon pain--a randomised controlled study with reliability testing of the evaluation methods. Scand J Med Sci Sports. 2001 Aug;11(4):197-206.

77. Stasinopoulos D, Stasinopoulos I. Comparison of effects of exercise programme, pulsed ultrasound and transverse friction in the treatment of chronic patellar tendinopathy. Clin Rehabil. 2004 Jun;18(4):347-52.

78. Steinmann S, Pfeifer CG, Brochhausen C, Docheva D. Spectrum of tendon pathologies: Triggers, trails and end-state. Int J Mol Sci. 2020 Jan 28;21(3):10.3390/ijms21030844.

79. Stergioulas A, Stergioula M, Aarskog R, Lopes-Martins RA, Bjordal JM. Effects of low-level laser therapy and eccentric exercises in the treatment of recreational athletes with chronic achilles tendinopathy. Am J Sports Med. 2008 May; $36(5): 881-7$.

80. Steunebrink M, Zwerver J, Brandsema R, Groenenboom P, van den AkkerScheek I, Weir A. Topical glyceryl trinitrate treatment of chronic patellar tendinopathy: A randomised, double-blind, placebo-controlled clinical trial. $\mathrm{Br} \mathrm{J}$ Sports Med. 2013 Jan;47(1):34-9.

81. Stevens M, Tan CW. Effectiveness of the alfredson protocol compared with a lower repetition-volume protocol for midportion achilles tendinopathy: A randomized controlled trial. J Orthop Sports Phys Ther. 2014 Feb;44(2):59-67.

82. Sussmilch-Leitch SP, Collins NJ, Bialocerkowski AE, Warden SJ, Crossley KM. Physical therapies for achilles tendinopathy: Systematic review and metaanalysis. J Foot Ankle Res. 2012 Jul 2;5(1):15,1146-5-15.

83. Thijs KM, Zwerver J, Backx FJ, Steeneken V, Rayer S, Groenenboom P, et al. Effectiveness of shockwave treatment combined with eccentric training for patellar tendinopathy: A double-blinded randomized study. Clin J Sport Med. 2017 Mar;27(2):89-96. 
84. Tumilty S, Mani R, Baxter GD. Photobiomodulation and eccentric exercise for achilles tendinopathy: A randomized controlled trial. Lasers Med Sci. 2016 Jan;31(1):127-35.

85. Tumilty S, McDonough S, Hurley DA, Baxter GD. Clinical effectiveness of lowlevel laser therapy as an adjunct to eccentric exercise for the treatment of achilles' tendinopathy: A randomized controlled trial. Arch Phys Med Rehabil. 2012 May;93(5):733-9.

86. van Ark M, Cook JL, Docking SI, Zwerver J, Gaida JE, van den Akker-Scheek I, et al. Do isometric and isotonic exercise programs reduce pain in athletes with patellar tendinopathy in-season? A randomised clinical trial. J Sci Med Sport. 2016 Sep;19(9):702-6.

87. van der Vlist AC, Breda SJ, Oei EHG, Verhaar JAN, de Vos RJ. Clinical risk factors for achilles tendinopathy: A systematic review. $\mathrm{Br}$ J Sports Med. 2019 Nov;53(21):1352-61.

88. Vander Doelen T, Jelley W. Non-surgical treatment of patellar tendinopathy: A systematic review of randomized controlled trials. J Sci Med Sport. 2020 Feb;23(2):118-24.

89. Visnes $\mathrm{H}$, Bahr R. The evolution of eccentric training as treatment for patellar tendinopathy (jumper's knee): A critical review of exercise programmes. $\mathrm{Br} \mathrm{J}$ Sports Med. 2007 Apr;41(4):217-23.

90. Waugh CM, Alktebi T, de Sa A, Scott A. Impact of rest duration on achilles tendon structure and function following isometric training. Scand J Med Sci Sports. 2018 Feb;28(2):436-45.

91. Wheeler PC. The addition of a tension night splint to a structured home rehabilitation programme in patients with chronic plantar fasciitis does not lead to significant additional benefits in either pain, function or flexibility: A single-blinded randomised controlled trial. BMJ Open Sport Exerc Med. 2017 Jun $13 ; 3(1): e 000234$. 
92. Yelland MJ, Sweeting KR, Lyftogt JA, Ng SK, Scuffham PA, Evans KA. Prolotherapy injections and eccentric loading exercises for painful achilles tendinosis: A randomised trial. Br J Sports Med. 2011 Apr;45(5):421-8.

93. Young MA, Cook JL, Purdam CR, Kiss ZS, Alfredson H. Eccentric decline squat protocol offers superior results at 12 months compared with traditional eccentric protocol for patellar tendinopathy in volleyball players. $\mathrm{Br}$ J Sports Med. 2005 Feb;39(2):102-5. 
Table 3: Study characteristics

\begin{tabular}{|c|c|c|c|c|c|c|c|c|}
\hline Author & Tendinopathy & $\begin{array}{l}\text { Intervention } \\
\text { groups }\end{array}$ & $\begin{array}{l}\text { Sample } \\
\text { size }\end{array}$ & $\begin{array}{l}\text { Intervention } \\
\text { duration } \\
\text { (wks) }\end{array}$ & $\begin{array}{l}\text { Outcomes }+ \\
\text { measures }\end{array}$ & $\begin{array}{l}\text { Follow- } \\
\text { up } \\
\text { length } \\
\text { (weeks) }\end{array}$ & Outcomes/ results & $\begin{array}{l}\text { Quality } \\
\text { score }\end{array}$ \\
\hline $\begin{array}{l}\text { Beyer et al. } \\
2015\end{array}$ & Achilles & $\begin{array}{l}\text { 1. HSRT } \\
\text { 2. ECCT }\end{array}$ & 58 & 12 & $\begin{array}{l}\text { Pain (VAS), } \\
\text { Function } \\
\text { (VISA-A), } \\
\text { Ultrasound }\end{array}$ & 52 & $\begin{array}{l}\text { Both interventions were effective, } \\
\text { with HSRT having greater patient } \\
\text { satisfaction at } 12 \text { but not } 52 \text { weeks. }\end{array}$ & 5 \\
\hline $\begin{array}{l}\text { Kongsgaard } \\
\text { et al. } 2009\end{array}$ & Patellar & $\begin{array}{l}\text { 1. CSI } 2 . \\
\text { HSRT 3. ECCT }\end{array}$ & 37 & 12 & $\begin{array}{l}\text { Pain (VAS), } \\
\text { Function } \\
\text { (VISA-P), } \\
\text { Ultrasound }\end{array}$ & 26 & $\begin{array}{l}\text { All groups improved, with only } \\
\text { exercise groups maintaining } \\
\text { improvements at } 6 \text { months. HSRT has } \\
\text { good short- and long-term clinical } \\
\text { effects. }\end{array}$ & 5 \\
\hline $\begin{array}{l}\text { Riel et al. } \\
2019\end{array}$ & Plantar heel & $\begin{array}{l}\text { 1. fixed HSRT } \\
\text { 2. Self-dosed } \\
\text { HSRT }\end{array}$ & 70 & 12 & $\begin{array}{l}\text { Function } \\
\text { (FHSQ), Pain } \\
\text { (self- } \\
\text { efficacy), } \\
\text { ultrasound }\end{array}$ & 12 & $\begin{array}{l}\text { Both groups improved pain and } \\
\text { function, with no significant } \\
\text { differences between groups. }\end{array}$ & 5 \\
\hline $\begin{array}{l}\text { Stevens \& } \\
\text { Tan } 2014\end{array}$ & Achilles & $\begin{array}{l}\text { 1. fixed ECCT } \\
\text { 2. Self-dosed } \\
\text { ECCT }\end{array}$ & 28 & 6 & $\begin{array}{l}\text { Pain (VAS), } \\
\text { Function } \\
\text { (VISA-A) } \\
\end{array}$ & 6 & $\begin{array}{l}\text { Both groups improved pain and } \\
\text { function, with no significant } \\
\text { differences between groups. }\end{array}$ & 5 \\
\hline $\begin{array}{l}\text { Da Cunha et } \\
\text { al. } 2012\end{array}$ & Patellar & $\begin{array}{l}\text { 1. ECCT pain } \\
\text { 2. ECCT no } \\
\text { pain }\end{array}$ & 17 & 12 & $\begin{array}{l}\text { Pain (VAS), } \\
\text { Function } \\
\text { (VISA-P) }\end{array}$ & 12 & $\begin{array}{l}\text { No difference between groups, both } \\
\text { groups improved pain and function. }\end{array}$ & 3 \\
\hline $\begin{array}{l}\text { Kulig et al. } \\
2009\end{array}$ & Posterior tibial & $\begin{array}{l}\text { 1. ECCT } 2 . \\
\text { CONCT } 3 . \\
\text { Orthoses }\end{array}$ & 36 & 12 & $\begin{array}{l}\text { Pain (VAS), } \\
\text { function } \\
\text { (FFI) }\end{array}$ & 12 & $\begin{array}{l}\text { Eccentric program was more effective } \\
\text { than concentric or orthoses alone. }\end{array}$ & 2 \\
\hline $\begin{array}{l}\text { Bahr et al. } \\
2006\end{array}$ & Patellar & $\begin{array}{l}\text { 1. ECCT } 2 . \\
\text { surgery }\end{array}$ & 35 & 12 & $\begin{array}{l}\text { Pain, } \\
\text { function } \\
\text { (VISA-P) }\end{array}$ & 12 & $\begin{array}{l}\text { Both groups improved, no significant } \\
\text { difference between groups. Trend } \\
\text { favouring ECCT. }\end{array}$ & 3 \\
\hline $\begin{array}{l}\text { Lee et al. } \\
2020\end{array}$ & Patellar & $\begin{array}{l}\text { 1. ECCT } 2 . \\
\text { ECCT + ESWT }\end{array}$ & 34 & 12 & $\begin{array}{l}\text { Pain (VAS), } \\
\text { function } \\
\text { (VISA-P), } \\
\text { ultrasound }\end{array}$ & 12 & $\begin{array}{l}\text { Combining exercise and ESWT could } \\
\text { not been shown to be more effective } \\
\text { than exercise alone }\end{array}$ & 2 \\
\hline $\begin{array}{l}\text { Frohm et al. } \\
2007\end{array}$ & Patellar & $\begin{array}{l}\text { 1. Standard } \\
\text { ECCT } 2 . \\
\text { Overload } \\
\text { ECCT }\end{array}$ & 20 & 12 & $\begin{array}{l}\text { Pain (VAS), } \\
\text { function } \\
\text { (VISA-P) }\end{array}$ & 12 & $\begin{array}{l}\text { Both treatment groups improved in } \\
\text { the short term, with no significant } \\
\text { difference between groups. }\end{array}$ & 4 \\
\hline
\end{tabular}




\begin{tabular}{|c|c|c|c|c|c|c|c|c|}
\hline $\begin{array}{l}\text { Silbernagel et } \\
\text { al. } 2001\end{array}$ & Achilles & $\begin{array}{l}\text { 1. Overload } \\
\text { ECCT } 2 \text {. } \\
\text { control }\end{array}$ & 40 & 12 & $\begin{array}{l}\text { Pain (VAS), } \\
\text { function, } \\
\text { task } \\
\text { performance }\end{array}$ & 52 & $\begin{array}{l}\text { No significant difference between } \\
\text { groups, at 1-year ECCT group more } \\
\text { satisfied with outcomes. }\end{array}$ & 2 \\
\hline $\begin{array}{l}\text { Balius et al. } \\
2016\end{array}$ & Achilles & $\begin{array}{l}\text { 1. ECCT } 2 . \\
\text { ECCT + } \\
\text { supplement } 3 . \\
\text { Supplement }+ \\
\text { stretching }\end{array}$ & 59 & 12 & $\begin{array}{l}\text { Pain (VAS), } \\
\text { function } \\
\text { (VISA-A), } \\
\text { ultrasound }\end{array}$ & 12 & $\begin{array}{l}\text { Reduction in pain at rest was greater } \\
\text { in the groups who took the } \\
\text { supplement than in the ECCT alone } \\
\text { group }\end{array}$ & 4 \\
\hline $\begin{array}{l}\text { Mafi et al. } \\
2001\end{array}$ & Achilles & $\begin{array}{l}\text { 1. ECCT } 2 . \\
\text { CONCT }\end{array}$ & 44 & 12 & $\begin{array}{l}\text { Pain (VAS), } \\
\text { function }\end{array}$ & 12 & $\begin{array}{l}\text { The results after treatment with } \\
\text { eccentric training was significantly } \\
\text { better }(P<0.002) \text { than after } \\
\text { concentric training. }\end{array}$ & 4 \\
\hline $\begin{array}{l}\text { Norregaard } \\
\text { et al. } 2007\end{array}$ & Achilles & $\begin{array}{l}\text { 1. ECCT } 2 . \\
\text { Stretching }\end{array}$ & 45 & 12 & $\begin{array}{l}\text { Manually } \\
\text { tested Pain, } \\
\text { function }\end{array}$ & 52 & $\begin{array}{l}\text { Marked improvement in symptoms } \\
\text { and findings could be gradually } \\
\text { observed in both groups during the } 1 \text { - } \\
\text { year follow-up period. }\end{array}$ & 4 \\
\hline $\begin{array}{l}\text { Stasinopolous } \\
\text { et al. } 2004\end{array}$ & Patellar & $\begin{array}{l}\text { 1. ECCT } 2 . \\
\text { Ultrasound } 3 . \\
\text { MT }\end{array}$ & 30 & 4 & Pain & 4 & $\begin{array}{l}\text { ECCT was statistically significantly } \\
\text { better than the other two treatments } \\
\text { at the end of treatment. }\end{array}$ & 4 \\
\hline $\begin{array}{l}\text { De Vos et al. } \\
2007\end{array}$ & Achilles & $\begin{array}{l}\text { 1. ECCT } 2 . \\
\text { ECCT + night } \\
\text { splint }\end{array}$ & 70 & 12 & $\begin{array}{l}\text { Pain, } \\
\text { function } \\
\text { (VISA-A) } \\
\end{array}$ & 12 & $\begin{array}{l}\text { Both groups improved pain and } \\
\text { function, with no significant difference } \\
\text { between groups }\end{array}$ & 5 \\
\hline $\begin{array}{l}\text { Johannsen et } \\
\text { al. } 2019\end{array}$ & Plantar Heel & $\begin{array}{l}\text { 1. HSRT } 2 . \\
\text { CSI 3. HSRT } \\
+ \text { CSI }\end{array}$ & 90 & 12 & $\begin{array}{l}\text { Pain (VAS), } \\
\text { function } \\
\text { (FFI), } \\
\text { ultrasound }\end{array}$ & 26 & $\begin{array}{l}\text { Combined treatment is superior both } \\
\text { in the short- and in the long-term. }\end{array}$ & 6 \\
\hline $\begin{array}{l}\text { MacDonald et } \\
\text { al. } 2019\end{array}$ & Patellar & $\begin{array}{l}\text { 1. ECCT } 2 . \\
\text { ECCT + hip } \\
\text { exercises }\end{array}$ & 41 & 12 & $\begin{array}{l}\text { Pain, } \\
\text { function } \\
\text { (VISA-P, } \\
\text { LEFS) }\end{array}$ & 24 & $\begin{array}{l}\text { Favourable effects were } \\
\text { demonstrated with combined } \\
\text { treatment of eccentric squat and hip } \\
\text { muscle strengthening or squat only }\end{array}$ & 2 \\
\hline $\begin{array}{l}\text { Gatz et al. } \\
2020\end{array}$ & Achilles & $\begin{array}{l}\text { 1. ECCT } 2 . \\
\text { ECCT }+ \\
\text { isometric }\end{array}$ & 42 & 12 & $\begin{array}{l}\text { Pain, } \\
\text { function } \\
\text { (VISA-A), } \\
\text { shear wave } \\
\text { elastography }\end{array}$ & 12 & $\begin{array}{l}\text { Isometric exercises do not have } \\
\text { additional benefit when combined } \\
\text { with eccentric exercises, as assessed } \\
\text { over a 3-month intervention period. }\end{array}$ & 3 \\
\hline $\begin{array}{l}\text { Ganderton et } \\
\text { al. } 2018\end{array}$ & Gluteal & $\begin{array}{l}\text { 1. Ex 2. Sham } \\
\text { Ex }\end{array}$ & 94 & 12 & $\begin{array}{l}\text { Pain, } \\
\text { function } \\
\text { (VISA-G) }\end{array}$ & 52 & $\begin{array}{l}\text { Lack of treatment effect was found } \\
\text { with the addition of an exercise } \\
\text { program to education }\end{array}$ & 5 \\
\hline
\end{tabular}




\begin{tabular}{|c|c|c|c|c|c|c|c|c|}
\hline $\begin{array}{l}\text { Silbernagel et } \\
\text { al. } 2007\end{array}$ & Achilles & $\begin{array}{l}\text { 1. Rehab with } \\
\text { continued } \\
\text { sports } 2 \text {. } \\
\text { Control }\end{array}$ & 38 & 12 & $\begin{array}{l}\text { Pain (VAS), } \\
\text { function } \\
\text { (VISA-A) }\end{array}$ & 26 & $\begin{array}{l}\text { Significant improvement and no } \\
\text { negative effects demonstrated from } \\
\text { continuing Achilles tendon-loading } \\
\text { activity, such as running and } \\
\text { jumping, with the use of a pain- } \\
\text { monitoring model, during treatment. }\end{array}$ & 6 \\
\hline $\begin{array}{l}\text { Clifford et al. } \\
2019\end{array}$ & Gluteal & $\begin{array}{l}\text { 1. isometric } \\
\text { Ex 2. Isotonic } \\
\text { Ex }\end{array}$ & 30 & 12 & $\begin{array}{l}\text { Pain (NRS), } \\
\text { function } \\
\text { (VISA-G), } \\
\text { QoL }\end{array}$ & 12 & $\begin{array}{l}\text { Both groups effective in reducing pain } \\
\text { and improving function, no difference } \\
\text { between groups. }\end{array}$ & 2 \\
\hline $\begin{array}{l}\text { Stergioulas et } \\
\text { al. } 2008\end{array}$ & Achilles & $\begin{array}{l}\text { 1. ECCT }+ \\
\text { LLLT 2. ECCT }\end{array}$ & 52 & 8 & $\begin{array}{l}\text { Pain (VAS), } \\
\text { function } \\
\text { (VISA-A) }\end{array}$ & 12 & $\begin{array}{l}\text { LLLT accelerates clinical recovery } \\
\text { when added to ECCT }\end{array}$ & 3 \\
\hline $\begin{array}{l}\text { Rompe et al. } \\
2008\end{array}$ & Achilles & $\begin{array}{l}\text { 1. ECCT } 2 . \\
\text { ESWT }\end{array}$ & 50 & 12 & $\begin{array}{l}\text { Pain, } \\
\text { function } \\
\text { (VISA-A) }\end{array}$ & 16 & ESWT superior to ECCT at 16 weeks. & 6 \\
\hline $\begin{array}{l}\text { Mellor et al. } \\
2018\end{array}$ & Gluteal & $\begin{array}{l}\text { 1. Ex, } \\
\text { education } 2 . \\
\text { CSI 3. control }\end{array}$ & 204 & 8 & $\begin{array}{l}\text { Pain (NRS), } \\
\text { function } \\
\text { (VISA-G), } \\
\text { QoL (EQ5D), } \\
\text { GROC }\end{array}$ & 52 & $\begin{array}{l}\text { At } 52 \text {-week follow-up, education plus } \\
\text { exercise led to better global } \\
\text { improvement than corticosteroid } \\
\text { injection use, but no difference in } \\
\text { pain intensity }\end{array}$ & 6 \\
\hline $\begin{array}{l}\text { Van Ark et al. } \\
2016\end{array}$ & Patellar & $\begin{array}{l}\text { 1. isotonic Ex } \\
\text { 2. Isometric } \\
\text { Ex }\end{array}$ & 29 & 4 & $\begin{array}{l}\text { Pain (NRS), } \\
\text { function } \\
\text { (SLDS) }\end{array}$ & 4 & $\begin{array}{l}\text { Both isometric and isotonic exercise } \\
\text { programs improved pain and function }\end{array}$ & 3 \\
\hline $\begin{array}{l}\text { Roos et al. } \\
2004\end{array}$ & Achilles & $\begin{array}{l}\text { 1. ECCT } 2 \text {. } \\
\text { ECCT + night } \\
\text { splint } 3 . \text { Night } \\
\text { splint }\end{array}$ & 44 & 6 & $\begin{array}{l}\text { Pain, } \\
\text { function } \\
\text { (FAOS) }\end{array}$ & 52 & $\begin{array}{l}\text { ECCT more effective than night splint } \\
\text { for improving pain and function }\end{array}$ & 2 \\
\hline $\begin{array}{l}\text { Chester et al. } \\
2008\end{array}$ & Achilles & $\begin{array}{l}\text { 1. ECCT } 2 . \\
\text { Ultrasound }\end{array}$ & 16 & 12 & $\begin{array}{l}\text { Pain (VAS), } \\
\text { function } \\
\text { (FILLA), QoL } \\
\text { (EQ5D) }\end{array}$ & 12 & $\begin{array}{l}\text { There were no significant differences } \\
\text { between groups or clear trends over } \\
\text { time. Both interventions proved } \\
\text { acceptable with no adverse effects. }\end{array}$ & 3 \\
\hline $\begin{array}{l}\text { Rompe et al. } \\
2007\end{array}$ & Achilles & $\begin{array}{l}\text { 1. ECCT } 2 . \\
\text { ESWT } 3 . \\
\text { Control } \\
\end{array}$ & 75 & 12 & $\begin{array}{l}\text { Pain, } \\
\text { function } \\
\text { (VISA-A) }\end{array}$ & 16 & $\begin{array}{l}\text { ECCT and ESWT showed comparable } \\
\text { positive results. The wait-and-see } \\
\text { strategy was ineffective. }\end{array}$ & 6 \\
\hline $\begin{array}{l}\text { Thijs et al. } \\
2017\end{array}$ & Patellar & $\begin{array}{l}\text { 1. ECCT + } \\
\text { ESWT 2. ECCT }\end{array}$ & 52 & 12 & $\begin{array}{l}\text { Pain, } \\
\text { function } \\
\text { (VISA-P) }\end{array}$ & 12 & $\begin{array}{l}\text { No additional effect of ESWT to EECT } \\
\text { for pain and function improvement. }\end{array}$ & 4 \\
\hline $\begin{array}{l}\text { Horstmann et } \\
\text { al. } 2013\end{array}$ & Achilles & $\begin{array}{l}\text { 1. ECCT } 2 . \\
\text { Vibration }\end{array}$ & 58 & 12 & $\begin{array}{l}\text { Pain (VAS), } \\
\text { function, }\end{array}$ & 24 & $\begin{array}{l}\text { Pain improvements were greatest in } \\
\text { the eccentric group. }\end{array}$ & 4 \\
\hline
\end{tabular}




\begin{tabular}{|c|c|c|c|c|c|c|c|c|}
\hline & & $\begin{array}{l}\text { training } 3 . \\
\text { control }\end{array}$ & & & $\begin{array}{l}\text { tendon } \\
\text { structure }\end{array}$ & & & \\
\hline $\begin{array}{l}\text { Alfredson et } \\
\text { al. } 1998\end{array}$ & Achilles & $\begin{array}{l}\text { 1. ECCT 2. CT } \\
\text { control }\end{array}$ & 30 & 12 & Pain (VAS) & 12 & Significant improvement with ECCT & 2 \\
\hline $\begin{array}{l}\text { Alvarez et al. } \\
2006\end{array}$ & Posterior tibial & $\begin{array}{l}\text { 1. Strength Ex } \\
+ \text { orthoses } 2 \text {. } \\
\text { Stretching }+ \\
\text { orthoses }\end{array}$ & 39 & 12 & $\begin{array}{l}\text { Pain, } \\
\text { function } \\
\text { (FFI) }\end{array}$ & 12 & $\begin{array}{l}\text { Both groups significantly improved in } \\
\text { pain and function over the } 12 \text {-week } \\
\text { trial period. The self-report measures } \\
\text { showed minimal differences between } \\
\text { the treatment groups. }\end{array}$ & 3 \\
\hline $\begin{array}{l}\text { Kearney et } \\
\text { al. } 2013\end{array}$ & Achilles & $\begin{array}{l}\text { 1. ECCT } 2 . \\
\text { PRP injection }\end{array}$ & 20 & 12 & $\begin{array}{l}\text { Pain (VAS), } \\
\text { function } \\
\text { (VISA-A) }\end{array}$ & 26 & $\begin{array}{l}\text { Both interventions effective, with PRP } \\
\text { having better outcomes, however } \\
\text { there was no significant difference. }\end{array}$ & 5 \\
\hline $\begin{array}{l}\text { Tumilty et al. } \\
2012\end{array}$ & Achilles & $\begin{array}{l}\text { 1. ECCT } 2 . \\
\text { ECCT + LLLT }\end{array}$ & 40 & 12 & $\begin{array}{l}\text { Pain (VAS), } \\
\text { function } \\
\text { (VISA-A) }\end{array}$ & 52 & $\begin{array}{l}\text { There was no statistically significant } \\
\text { difference in VISA-A scores between } \\
\text { groups. }\end{array}$ & 6 \\
\hline $\begin{array}{l}\text { Yelland et al. } \\
2011\end{array}$ & Achilles & $\begin{array}{l}\text { 1. ECCT } 2 . \\
\text { ECCT }+ \\
\text { prolotherapy } \\
3 . \\
\text { prolotherapy }\end{array}$ & 43 & 12 & $\begin{array}{l}\text { Pain (VAS), } \\
\text { function } \\
\text { (VISA-A), } \\
\text { costs }\end{array}$ & 52 & $\begin{array}{l}\text { prolotherapy and particularly ECCT } \\
\text { combined with prolotherapy give } \\
\text { more rapid improvements in } \\
\text { symptoms than ECT alone but long- } \\
\text { term VISA-A scores are similar. }\end{array}$ & 5 \\
\hline $\begin{array}{l}\text { McCormack } \\
\text { et al. } 2016\end{array}$ & Achilles & $\begin{array}{l}\text { 1. ECCT } 2 . \\
\mathrm{ECCT}+\mathrm{MT}\end{array}$ & 16 & 12 & $\begin{array}{l}\text { Pain (NPRS), } \\
\text { function } \\
\text { (VISA-A) }\end{array}$ & 52 & $\begin{array}{l}\text { ECCT + MT more effective than ECCT } \\
\text { only at improving function during } \\
\text { both short- and long-term follow-up }\end{array}$ & 3 \\
\hline $\begin{array}{l}\text { Tumilty et al. } \\
2016\end{array}$ & Achilles & $\begin{array}{l}\text { 1. ECCT } 12 . \\
\text { ECCT } 1+ \\
\text { LLLT 3. ECCT } \\
24 . \text { ECCT } 2 \\
+ \text { LLLT }\end{array}$ & 80 & 12 & $\begin{array}{l}\text { Pain, } \\
\text { function } \\
\text { (VISA-A) }\end{array}$ & 12 & $\begin{array}{l}\text { Twice-daily exercise sessions are not } \\
\text { necessary as equivalent results can } \\
\text { be obtained with two exercise } \\
\text { sessions per week. The addition of } \\
\text { LLLT can bring added benefit. }\end{array}$ & 6 \\
\hline $\begin{array}{l}\text { Cannell et al. } \\
2001\end{array}$ & Patellar & $\begin{array}{l}\text { 1. ECCT } 2 . \\
\text { Isotonic Ex }\end{array}$ & 19 & 12 & $\begin{array}{l}\text { Pain (VAS), } \\
\text { return to } \\
\text { sport }\end{array}$ & 12 & $\begin{array}{l}\text { Progressive drop squats } \\
\text { and leg extension/curl exercises both } \\
\text { reduced pain and enable return to } \\
\text { sport }\end{array}$ & 3 \\
\hline $\begin{array}{l}\text { Jonsson et al. } \\
2005\end{array}$ & Patellar & $\begin{array}{l}\text { 1. ECCT 2, } \\
\text { CONCT }\end{array}$ & 19 & 12 & $\begin{array}{l}\text { Pain (VAS), } \\
\text { function, } \\
\text { (VISA-P) }\end{array}$ & 12 & $\begin{array}{l}\text { eccentric, but not concentric, } \\
\text { quadriceps training on a decline } \\
\text { board, seems to reduce pain in PT }\end{array}$ & 1 \\
\hline $\begin{array}{l}\text { Kedia et al. } \\
2014\end{array}$ & Achilles & $\begin{array}{l}\text { 1. CT 2. ECCT } \\
+\mathrm{CT}\end{array}$ & 36 & 12 & $\begin{array}{l}\text { Pain (VAS), } \\
\text { function } \\
\text { (SF36) }\end{array}$ & 12 & $\begin{array}{l}\text { No significant differences between } \\
\text { groups. CT and ECCT both effective. }\end{array}$ & 5 \\
\hline
\end{tabular}




\begin{tabular}{|c|c|c|c|c|c|c|c|c|}
\hline $\begin{array}{l}\text { Herrington et } \\
\text { al. } 2007\end{array}$ & Achilles & $\begin{array}{l}\text { 1. } \mathrm{ECCT}+\mathrm{CT} \\
\text { 2. } \mathrm{CT}\end{array}$ & 25 & 12 & $\begin{array}{l}\text { Pain, } \\
\text { function } \\
\text { (VISA-A) }\end{array}$ & 12 & $\begin{array}{l}\text { ECCT + CT was more effective than } \\
\text { CT alone for pain and function. }\end{array}$ & 4 \\
\hline $\begin{array}{l}\text { Houck et al. } \\
2015\end{array}$ & Posterior tibial & $\begin{array}{l}\text { 1. Orthosis }+ \\
\text { stretching } 2 \text {. } \\
+ \text { strength Ex }\end{array}$ & 39 & 12 & $\begin{array}{l}\text { Pain, } \\
\text { function } \\
(\mathrm{FFI})\end{array}$ & 12 & $\begin{array}{l}\text { Both groups significantly improved in } \\
\text { pain and function over the } 12-\text { week } \\
\text { trial period. minimal differences } \\
\text { between the treatment groups. }\end{array}$ & 5 \\
\hline $\begin{array}{l}\text { Dimitrios et } \\
\text { al. } 2012\end{array}$ & Patellar & $\begin{array}{l}\text { 1. ECCT } 2 . \\
\text { ECCT }+ \\
\text { stretching }\end{array}$ & 43 & 4 & $\begin{array}{l}\text { Pain, } \\
\text { function } \\
\text { (VISA-P) }\end{array}$ & 24 & $\begin{array}{l}\text { ECCT and static stretching exercises } \\
\text { is superior to ECCT alone to reduce } \\
\text { pain and improve function }\end{array}$ & 3 \\
\hline $\begin{array}{l}\text { Petersen et } \\
\text { al. } 2007\end{array}$ & Achilles & $\begin{array}{l}\text { 1. ECCT } 2 . \\
\text { Brace 3. ECCT } \\
+ \text { brace }\end{array}$ & 100 & 12 & $\begin{array}{l}\text { Pain (VAS), } \\
\text { function } \\
\text { (AOFAS), } \\
\text { QoL (SF-36) }\end{array}$ & 54 & $\begin{array}{l}\text { The VAS score for pain, AOFAS score, } \\
\text { and SF- } 36 \text { improved significantly in } \\
\text { all } 3 \text { groups at all } 3 \text { follow-ups, no } \\
\text { significant difference between groups }\end{array}$ & 3 \\
\hline $\begin{array}{l}\text { Steunebrink } \\
\text { et al. } 2013\end{array}$ & Patellar & $\begin{array}{l}\text { 1. ECCT }+ \\
\text { GTN 2. ECCT }\end{array}$ & 33 & 12 & $\begin{array}{l}\text { Pain, } \\
\text { function } \\
\text { (VISA-P) }\end{array}$ & 24 & $\begin{array}{l}\text { GTN + ECCT does not improve clinical } \\
\text { outcome compared to placebo } \\
\text { patches + ECCT }\end{array}$ & 5 \\
\hline $\begin{array}{l}\text { Rompe et al. } \\
2009\end{array}$ & Achilles & $\begin{array}{l}\text { 1. ECCT + } \\
\text { ESWT 2. ECCT }\end{array}$ & 68 & 12 & $\begin{array}{l}\text { Pain, } \\
\text { function } \\
\text { (VISA-A) }\end{array}$ & 52 & $\begin{array}{l}\text { Combined ECCT + ESWT more } \\
\text { effective at } 4 \text { months follow-up }\end{array}$ & 5 \\
\hline $\begin{array}{l}\text { Young et al. } \\
2005\end{array}$ & Patellar & $\begin{array}{l}\text { 1. ECCT step } \\
\text { 2. ECCT } \\
\text { decline }\end{array}$ & 17 & 12 & $\begin{array}{l}\text { Pain (VAS), } \\
\text { function } \\
\text { (VISA-P) }\end{array}$ & 52 & $\begin{array}{l}\text { Both groups improved pain and } \\
\text { sporting function at } 12 \text { months. } \\
\text { Decline squat more effective. }\end{array}$ & 3 \\
\hline $\begin{array}{l}\text { De Jonge et } \\
\text { al. } 2010\end{array}$ & Achilles & $\begin{array}{l}\text { 1. ECCT } 2 . \\
\text { ECCT + night } \\
\text { splint }\end{array}$ & 58 & 12 & $\begin{array}{l}\text { Pain, } \\
\text { function } \\
\text { (VISA-A) }\end{array}$ & 52 & $\begin{array}{l}\text { ECCT with or without a night splint } \\
\text { improved functional outcome at } 1- \\
\text { year. no significant difference in } \\
\text { clinical outcome between groups. }\end{array}$ & 5 \\
\hline $\begin{array}{l}\text { Praet et al. } \\
2019\end{array}$ & Achilles & $\begin{array}{l}\text { 1. ECCT + } \\
\text { collagen } \\
\text { peptides }\end{array}$ & 20 & 26 & $\begin{array}{l}\text { Pain, } \\
\text { function } \\
\text { (VISA-A) }\end{array}$ & 26 & $\begin{array}{l}\text { Oral supplementation of collagen } \\
\text { peptides may accelerate the clinical } \\
\text { benefits of ECCT. }\end{array}$ & 5 \\
\hline $\begin{array}{l}\text { Rathleff et al. } \\
2015\end{array}$ & Plantar heel & $\begin{array}{l}\text { 1. HSRT } 2 . \\
\text { stretching }\end{array}$ & 48 & 12 & $\begin{array}{l}\text { Pain, } \\
\text { function } \\
\text { (FFI) }\end{array}$ & 52 & $\begin{array}{l}\text { HSRT superior to plantar fascia } \\
\text { stretching for pain and function }\end{array}$ & 3 \\
\hline $\begin{array}{l}\text { Knobloch et } \\
\text { al. } 2008\end{array}$ & Achilles & $\begin{array}{l}\text { 1. ECCT + } \\
\text { brace 2. ECCT }\end{array}$ & 116 & 12 & $\begin{array}{l}\text { Pain (VAS), } \\
\text { function } \\
\text { (FAOS) }\end{array}$ & 12 & $\begin{array}{l}\text { No additional effect of heel brace to } \\
\text { ECCT alone. }\end{array}$ & 4 \\
\hline $\begin{array}{l}\text { Wheeler et } \\
\text { al. } 2017\end{array}$ & Plantar heel & $\begin{array}{l}\text { 1. General Ex } \\
\text { 2. Ex + night } \\
\text { splint }\end{array}$ & 40 & 12 & $\begin{array}{l}\text { Pain (VAS), } \\
\text { Function } \\
\text { (FFI, FAAM) }\end{array}$ & 12 & $\begin{array}{l}\text { Improvement in both groups, with no } \\
\text { significant differences between } \\
\text { groups. }\end{array}$ & 5 \\
\hline
\end{tabular}


Table 4: Application of resistance training principles

\begin{tabular}{|c|c|c|c|c|c|c|c|c|c|c|c|c|}
\hline Author & $\begin{array}{l}\text { Spec } \\
\text { ificity }\end{array}$ & $\begin{array}{l}\text { Over } \\
\text { load }\end{array}$ & $\begin{array}{l}\text { Progression } \\
+ \text { method }\end{array}$ & $\begin{array}{l}\text { Individualised } \\
+ \text { method }\end{array}$ & $\begin{array}{l}\text { Frequency } \\
\text { (d/wk) }\end{array}$ & Intensity & $\begin{array}{l}\text { Time } \\
(\min )\end{array}$ & Sets & Reps & $\begin{array}{l}\text { Exercise } \\
\text { mode/type }\end{array}$ & Adherence & $\begin{array}{l}\text { RTP, } \\
\text { Total } \\
\text { score } \\
/ 10\end{array}$ \\
\hline $\begin{array}{l}\text { Beyer et al. } \\
2015\end{array}$ & $Y$ & $\mathrm{Y}$ & $\begin{array}{l}\text { Y, increase } \\
\text { resistance/ } \\
\text { load }\end{array}$ & $\begin{array}{l}\mathrm{Y} \text {, pain } \\
\text { response } 4- \\
5 / 10\end{array}$ & 3 & $\begin{array}{l}\text { 15RM - } \\
6 \mathrm{RM}\end{array}$ & $\begin{array}{l}107 \times \\
\text { wk } \\
\text { (HSRT) } \\
308 x \\
\text { wk } \\
\text { (ECCT) }\end{array}$ & $3-4$ & $15-6$ & $\begin{array}{l}\text { Heel raises, with } \\
\text { external weights }\end{array}$ & Y, diary & 7,9 \\
\hline $\begin{array}{l}\text { Kongsgaard } \\
\text { et al. } 2009\end{array}$ & $Y$ & $\mathrm{Y}$ & $\begin{array}{l}\mathrm{Y} \text {, increase } \\
\text { resistance }\end{array}$ & NR & 3 & $\begin{array}{l}\text { 15RM - } \\
6 R M\end{array}$ & NR & $3-4$ & $15-6$ & $\begin{array}{l}\text { DSL squats, squat, } \\
\text { leg press, hack } \\
\text { squat, with } \\
\text { external weights }\end{array}$ & NR & 5,5 \\
\hline $\begin{array}{l}\text { Riel et al. } \\
2019\end{array}$ & $Y$ & $\mathrm{Y}$ & $\begin{array}{l}\text { Y, increase } \\
\text { resistance } \\
\text { or volume }\end{array}$ & $\begin{array}{l}\mathrm{Y} \text {, as many } \\
\text { sets as } \\
\text { possible }\end{array}$ & 3 & $\begin{array}{l}8 \mathrm{RM}- \\
12 \mathrm{RM}\end{array}$ & tut & $\begin{array}{l}3-5, \\
\text { AMAP }\end{array}$ & $8-12$ & $\begin{array}{l}\text { Heel raises, loaded } \\
\text { backpack }\end{array}$ & $\begin{array}{l}\text { Y, diary, } \\
20 \text { not } \\
\text { returned }\end{array}$ & 7,9 \\
\hline $\begin{array}{l}\text { Stevens \& } \\
\text { Tan } 2014\end{array}$ & $Y$ & $\mathrm{Y}$ & $\begin{array}{l}\text { Y, increase } \\
\text { resistance } \\
\text { or volume }\end{array}$ & $\begin{array}{l}\mathrm{Y} \text {, as many } \\
\text { reps as } \\
\text { possible }\end{array}$ & $7,2 \times d$ & $15 \mathrm{RM}$ & NR & $\begin{array}{l}2 \times 6 \\
(12)\end{array}$ & $\begin{array}{l}15 \\
(180 \\
\text { total })\end{array}$ & $\begin{array}{l}\text { Heel raises } \\
\text { (straight leg \& } \\
\text { bent knee), loaded } \\
\text { backpack }\end{array}$ & $\mathrm{Y}$, diary & 7,9 \\
\hline $\begin{array}{l}\text { Da Cunha et } \\
\text { al. } 2012\end{array}$ & $\mathrm{Y}$ & $\mathrm{Y}$ & $\begin{array}{l}\text { Y, increase } \\
\text { resistance } \\
(5 \mathrm{~kg} \text { inc) } \\
\end{array}$ & $\begin{array}{l}\text { Y, pain } \\
\text { response }\end{array}$ & 3 & $15 R M$ & NR & 3 & 15 & $\begin{array}{l}\text { Eccentric decline } \\
\text { squat }\end{array}$ & NR & 8,8 \\
\hline $\begin{array}{l}\text { Kulig et al. } \\
2009\end{array}$ & $\mathrm{Y}$ & $\mathrm{Y}$ & $\begin{array}{l}\text { Y, increase } \\
\text { resistance } \\
(0.9 \mathrm{~kg} \\
\text { conforce } \\
\text { spring) }\end{array}$ & $\begin{array}{l}\text { Y, increase } \\
\text { isokinetic } \\
\text { resistance as } \\
\text { able }\end{array}$ & $7,2 \times d$ & 15RM & NR & $\begin{array}{l}2 \times 3 \\
(6)\end{array}$ & $\begin{array}{l}15 \\
(180)\end{array}$ & $\begin{array}{l}\text { Isokinetic resisted } \\
\text { horizontal } \\
\text { adduction with } \\
\text { plantar flexion }\end{array}$ & $\begin{array}{l}\text { Y, diary, } \\
68 \%(39- \\
98)\end{array}$ & 8,10 \\
\hline $\begin{array}{l}\text { Bahr et al. } \\
2006\end{array}$ & $\mathrm{Y}$ & $Y$ & $\begin{array}{l}\text { Y, increase } \\
\text { resistance } \\
(5 \mathrm{~kg} \text { inc) }\end{array}$ & $\begin{array}{l}\mathrm{Y}, \text { pain } \\
\text { response less } \\
3 / 10, \\
\text { increase } 5 \mathrm{~kg}\end{array}$ & $7,2 \times d$ & 15RM & NR & $\begin{array}{l}2 \times 3 \\
(6)\end{array}$ & $\begin{array}{l}15 \\
(180)\end{array}$ & $\begin{array}{l}\text { DSL squat, loaded } \\
\text { backpack }\end{array}$ & NR & 8,8 \\
\hline $\begin{array}{l}\text { Lee et al. } \\
2020\end{array}$ & $Y$ & $Y$ & $\begin{array}{l}\text { Y, increase } \\
\text { resistance } \\
(5 \mathrm{~kg} \text { inc) } \\
\end{array}$ & $\begin{array}{l}\mathrm{Y}, \text { pain } \\
\text { response }\end{array}$ & $7,2 \times d$ & $15 R M$ & NR & $\begin{array}{l}2 \times 3 \\
(6)\end{array}$ & $\begin{array}{l}15 \\
(180)\end{array}$ & $\begin{array}{l}\text { DSL squat, loaded } \\
\text { backpack }\end{array}$ & Y, diary & 8,10 \\
\hline
\end{tabular}




\begin{tabular}{|c|c|c|c|c|c|c|c|c|c|c|c|c|}
\hline & & & & $\begin{array}{l}4 / 10, \\
\text { increase } 5 \mathrm{~kg}\end{array}$ & & & & & & & & \\
\hline $\begin{array}{l}\text { Frohm et al. } \\
2007\end{array}$ & $Y$ & $\mathrm{Y}$ & $\begin{array}{l}\text { Y, increase } \\
\text { resistance } \\
(5 \mathrm{~kg} \text { inc) }\end{array}$ & $\begin{array}{l}\mathrm{Y}, \text { pain } \\
\text { response } \\
5 / 10, \\
\text { increase } 5 \mathrm{~kg}\end{array}$ & $\begin{array}{l}1.22 .7 \\
2 \times d\end{array}$ & 15-16RM & $\begin{array}{l}70 \\
\text { mins } x \\
\text { session }\end{array}$ & $3-4$ & $\begin{array}{l}15- \\
16\end{array}$ & $\begin{array}{l}\text { 1. The Bromsman } \\
\text { eccentric overload } \\
\text { training device } 2 \text {. } \\
\text { DSL squat, loaded } \\
\text { backpack }\end{array}$ & NR & 8,8 \\
\hline $\begin{array}{l}\text { Silbernagel et } \\
\text { al. } 2001\end{array}$ & $Y$ & $\mathrm{Y}$ & $\begin{array}{l}\text { Y, increase } \\
\text { resistance, } \\
\text { volume, } \\
\text { speed \& } \\
\text { difficultly }\end{array}$ & $\begin{array}{l}\mathrm{Y} \text {, pain } \\
\text { response } \\
5 / 10\end{array}$ & 7 & 5-15RM & NR & 3 & $5-15$ & $\begin{array}{l}\text { Double and single } \\
\text { leg Slow Heel } \\
\text { raises, fast } \\
\text { rebounding heel } \\
\text { raises }\end{array}$ & Y, diary & 7,9 \\
\hline $\begin{array}{l}\text { Balius et al. } \\
2016\end{array}$ & $Y$ & UC & UC & UC & $7,2 x d$ & $15 R M$ & NR & $\begin{array}{l}2 \times 3 \\
(6)\end{array}$ & $\begin{array}{l}15 \\
(180)\end{array}$ & $\begin{array}{l}\text { Alfredson heel } \\
\text { raises, straight \& } \\
\text { bent knee }\end{array}$ & $\begin{array}{l}\text { PT } \\
\text { recorded; } \\
70 \% \\
\text { minimum } \\
\text { allowed }\end{array}$ & 2,4 \\
\hline $\begin{array}{l}\text { Mafi et al. } \\
2001\end{array}$ & $Y$ & $Y$ & $\begin{array}{l}\mathrm{Y} \text {, increase } \\
\text { resistance }\end{array}$ & $\begin{array}{l}\mathrm{Y} \text {, pain } \\
\text { response }\end{array}$ & $7,2 \times d$ & $15 R M$ & NR & $\begin{array}{l}2 \times 3 \\
(6)\end{array}$ & $\begin{array}{l}15 \\
(180)\end{array}$ & $\begin{array}{l}\text { Alfredson heel } \\
\text { raises, straight \& } \\
\text { bent knee, loaded } \\
\text { with backpack or } \\
\text { weight machines }\end{array}$ & NR & 7,7 \\
\hline $\begin{array}{l}\text { Norregaard } \\
\text { et al. } 2007\end{array}$ & $\mathrm{Y}$ & $Y$ & $\begin{array}{l}\mathrm{Y}, \text { increase } \\
\text { resistance } \\
(5 \mathrm{~kg} \text { inc) }\end{array}$ & $\begin{array}{l}\mathrm{Y}, \text { pain } \\
\text { response, } \\
\text { increase } 5 \mathrm{~kg}\end{array}$ & $7,2 \times d$ & 15RM & NR & $\begin{array}{l}2 \times 3 \\
(6)\end{array}$ & $\begin{array}{l}15 \\
(180)\end{array}$ & $\begin{array}{l}\text { Alfredson heel } \\
\text { raises, straight \& } \\
\text { bent knee, loaded } \\
\text { with backpack }\end{array}$ & $\begin{array}{l}\text { Y. diary, } \\
\text { results NR }\end{array}$ & 8,9 \\
\hline $\begin{array}{l}\text { Stasinopolous } \\
\text { et al. } 2004\end{array}$ & $\mathrm{Y}$ & $Y$ & $\begin{array}{l}\mathrm{Y}, \text { increase } \\
\text { resistance }\end{array}$ & $\begin{array}{l}\mathrm{Y}, \text { pain } \\
\text { response }\end{array}$ & $7,2 \times d$ & 15RM & NR & $\begin{array}{l}2 \times 3 \\
(6)\end{array}$ & $\begin{array}{l}15 \\
(180)\end{array}$ & $\begin{array}{l}\text { DSL squat, } \\
\text { handheld external } \\
\text { weights }\end{array}$ & NR & 8,8 \\
\hline $\begin{array}{l}\text { De Vos et al. } \\
2007\end{array}$ & $\mathrm{Y}$ & $Y$ & $\begin{array}{l}\mathrm{Y} \text {, increase } \\
\text { resistance }\end{array}$ & $\begin{array}{l}\mathrm{Y} \text {, pain } \\
\text { response }\end{array}$ & $7,2 \times d$ & 15RM & NR & $\begin{array}{l}2 \times 3 \\
(6)\end{array}$ & $\begin{array}{l}15 \\
(180)\end{array}$ & $\begin{array}{l}\text { Alfredson heel } \\
\text { raises, straight \& } \\
\text { bent knee, loaded } \\
\text { with backpack or } \\
\text { weight machines }\end{array}$ & Y, diary & 7,9 \\
\hline $\begin{array}{l}\text { Johannsen et } \\
\text { al. } 2019\end{array}$ & $Y$ & UC & UC & NR & 3 & NR & NR & NR & NR & $\begin{array}{l}\text { (1) heel-rises, ( } 2) \\
\text { flexion of the first } \\
\text { toe against elastic } \\
\text { band. ( } 3 \text { ) } \\
\text { Inversion of the }\end{array}$ & NR & 2,2 \\
\hline
\end{tabular}




\begin{tabular}{|c|c|c|c|c|c|c|c|c|c|c|c|c|}
\hline & & & & & & & & & & $\begin{array}{l}\text { foot against elastic } \\
\text { band }\end{array}$ & & \\
\hline $\begin{array}{l}\text { MacDonald et } \\
\text { al. } 2019\end{array}$ & $Y$ & $\mathrm{Y}$ & $\begin{array}{l}Y, \text { increase } \\
\text { resistance } \\
(5 \mathrm{~kg} \text { inc) }\end{array}$ & $\begin{array}{l}\text { Y, pain } \\
\text { response } \\
5 / 10, \\
\text { increase } 5 \mathrm{~kg}, \\
\text { correct } \\
\text { technique }\end{array}$ & $7,2 \times d$ & $15 R M$ & NR & $\begin{array}{l}2 \times 3 \\
(6)\end{array}$ & $\begin{array}{l}15 \\
(180)\end{array}$ & $\begin{array}{l}\text { DSL squat } \\
\text { eccentric protocol } \\
\text { with addition of } \\
\text { isotonic hip } \\
\text { exercise, loaded } \\
\text { backpack }\end{array}$ & $\begin{array}{l}\text { Y, diary, } \\
42.5 \% \text { full }\end{array}$ & 8,10 \\
\hline $\begin{array}{l}\text { Gatz et al. } \\
2020\end{array}$ & $Y$ & $\mathrm{Y}$ & $\begin{array}{l}Y \text {, increase } \\
\text { resistance }\end{array}$ & $\begin{array}{l}\text { Y, pain } \\
\text { response }\end{array}$ & $7,2 \times D$ & $15 R M$ & NR & $\begin{array}{l}2 \times 3 \\
(6)\end{array}$ & $\begin{array}{l}15 \\
(180)\end{array}$ & $\begin{array}{l}\text { Alfredson eccentric } \\
\text { heel raise protocol } \\
+ \text { isometric } \\
\text { exercise }\end{array}$ & $\begin{array}{l}\text { Y, verbal, } \\
\text { NR }\end{array}$ & 7,8 \\
\hline $\begin{array}{l}\text { Ganderton et } \\
\text { al. } 2018\end{array}$ & $Y$ & $\mathrm{Y}$ & $\begin{array}{l}\text { Y, increase } \\
\text { difficulty }\end{array}$ & $\begin{array}{l}\text { Y, individual } \\
\text { ability } \\
\text { determined } \\
\text { progression }\end{array}$ & $7,2 \times d$ & 5-15RM & $\begin{array}{l}\text { 30MIN } \\
\text { X D }\end{array}$ & $2-4$ & $5-15$ & $\begin{array}{l}\text { isometric loading } \\
\text { of gluteals, and } \\
\text { kinetic chain } \\
\text { strength exercises }\end{array}$ & Y, diary & 6,8 \\
\hline $\begin{array}{l}\text { Silbernagel et } \\
\text { al. } 2007\end{array}$ & $Y$ & $\mathrm{Y}$ & $\begin{array}{l}\text { Y, Increase } \\
\text { resistance, } \\
\text { volume and } \\
\text { speed of } \\
\text { exercises }\end{array}$ & $\begin{array}{l}\text { Y, Increased } \\
\text { resistance, } \\
\text { volume and } \\
\text { speed guided } \\
\text { by Pain } \\
\text { response }\end{array}$ & 7 & 10-20RM & NR & 3 & $\begin{array}{l}10- \\
20\end{array}$ & $\begin{array}{l}\text { 2-legged, 1- } \\
\text { legged, eccentric, } \\
\text { and fast } \\
\text { rebounding toe } \\
\text { raises, plyometric } \\
\text { exercise. Loaded } \\
\text { with backpack or } \\
\text { weight machine }\end{array}$ & Y, diary & 7,9 \\
\hline $\begin{array}{l}\text { Clifford et al. } \\
2019\end{array}$ & $\mathrm{Y}$ & $Y$ & $\begin{array}{l}\mathrm{Y} \text {, increase } \\
\text { resistance } \\
\text { band } \\
\text { strength }\end{array}$ & $\begin{array}{l}\mathrm{Y} \text {, pain } \\
\text { response } \\
5 / 10\end{array}$ & 7 & 6-10RM & $\begin{array}{l}6 \min \\
\text { TUT } x \\
d\end{array}$ & $3-6$ & $6-10$ & $\begin{array}{l}\text { Isotonic \& } \\
\text { isometric hip } \\
\text { abduction, loaded } \\
\text { with bands }\end{array}$ & Y, diary & 7,9 \\
\hline $\begin{array}{l}\text { Stergioulas et } \\
\text { al. } 2008\end{array}$ & $\mathrm{Y}$ & $\mathrm{Y}$ & $\begin{array}{l}\mathrm{Y}, \text { increase } \\
\text { resistance } \\
(4 \mathrm{~kg} \text { inc })\end{array}$ & $\begin{array}{l}\mathrm{Y}, \text { pain } \\
\text { response } \\
5 / 10\end{array}$ & 4 & $12 \mathrm{RM}$ & NR & 12 & 12 & $\begin{array}{l}\text { Eccentric heel } \\
\text { raise, knee } \\
\text { straight \& flexed, } \\
\text { loaded backpack }\end{array}$ & $\mathrm{Y}, \mathrm{NR}$ & 8,9 \\
\hline $\begin{array}{l}\text { Rompe et al. } \\
2008\end{array}$ & $Y$ & $\mathrm{Y}$ & $\begin{array}{l}Y, \text { increase } \\
\text { resistance } \\
(5 \mathrm{~kg} \text { inc) }\end{array}$ & $\begin{array}{l}\mathrm{Y}, \text { pain } \\
\text { response, } \\
\text { increase } 5 \mathrm{~kg}\end{array}$ & $7,2 \times D$ & 10-15RM & NR & $\begin{array}{l}3 \times 2 \\
(6)\end{array}$ & $\begin{array}{l}10- \\
15 \\
(180)\end{array}$ & $\begin{array}{l}\text { Alfredson eccentric } \\
\text { heel raise, knee } \\
\text { straight \& flexed, } \\
\text { loaded backpack }\end{array}$ & $\begin{array}{l}\text { Y, verbal, } \\
\text { NR }\end{array}$ & 8,9 \\
\hline $\begin{array}{l}\text { Van Ark et al. } \\
2016\end{array}$ & $Y$ & $Y$ & $\begin{array}{l}\text { Y, increase } \\
\text { resistance } \\
2.5 \% \text { per } \\
\text { week }\end{array}$ & $\begin{array}{l}\text { Y, pain } \\
\text { response, } \\
\text { correct } \\
\text { technique, }\end{array}$ & 4 & $\begin{array}{l}\text { isometric } \\
(80 \% \\
1 \mathrm{RM}) \\
\text { isotonic }\end{array}$ & NR & $4-5$ & $5-8$ & $\begin{array}{l}\text { Leg extension } \\
\text { machine, external } \\
\text { weight. Audio used } \\
\text { for speed tempo }\end{array}$ & NR & 8,8 \\
\hline
\end{tabular}




\begin{tabular}{|c|c|c|c|c|c|c|c|c|c|c|c|c|}
\hline & & & & $\begin{array}{l}2.5 \% \\
\text { increase }\end{array}$ & & $\begin{array}{l}\text { (80\% } \\
8 R M)\end{array}$ & & & & & & \\
\hline $\begin{array}{l}\text { Roos et al. } \\
2004\end{array}$ & $Y$ & $\mathrm{Y}$ & $\begin{array}{l}\mathrm{Y} \text {, increase } \\
\text { resistance }\end{array}$ & $\begin{array}{l}\mathrm{Y} \text {, pain } \\
\text { response }\end{array}$ & $7,2 \times D$ & $15 R M$ & NR & $1-3$ & $\begin{array}{l}15 \\
(180)\end{array}$ & $\begin{array}{l}\text { Modified Alfredson } \\
\text { eccentric heel } \\
\text { raise, knee } \\
\text { straight \& flexed, } \\
\text { loaded backpack }\end{array}$ & NR & 7,7 \\
\hline $\begin{array}{l}\text { Chester et al. } \\
2008\end{array}$ & $Y$ & $\mathrm{Y}$ & $\begin{array}{l}\mathrm{Y} \text {, increase } \\
\text { resistance }\end{array}$ & $\begin{array}{l}\mathrm{Y}, \text { pain } \\
\text { response }\end{array}$ & 7 & $15 R M$ & NR & $\begin{array}{l}3 \times 2 \\
(6)\end{array}$ & $\begin{array}{l}15 \\
(90)\end{array}$ & $\begin{array}{l}\text { Modified Alfredson } \\
\text { eccentric heel } \\
\text { raise, knee } \\
\text { straight \& flexed, } \\
\text { loaded backpack }\end{array}$ & NR & 7,7 \\
\hline $\begin{array}{l}\text { Rompe et al. } \\
2007\end{array}$ & $Y$ & $\mathrm{Y}$ & $\begin{array}{l}\text { Y, increase } \\
\text { resistance } \\
(5 \mathrm{~kg} \text { inc) }\end{array}$ & $\begin{array}{l}\mathrm{Y}, \text { pain } \\
\text { response, } \\
\text { increase } 5 \mathrm{~kg}\end{array}$ & $7,2 \times D$ & 10-15RM & NR & $\begin{array}{l}3 \times 2 \\
(6)\end{array}$ & $\begin{array}{l}10- \\
15 \\
(180)\end{array}$ & $\begin{array}{l}\text { Modified Alfredson } \\
\text { eccentric heel } \\
\text { raise, knee } \\
\text { straight \& flexed, } \\
\text { loaded backpack }\end{array}$ & NR & 8,8 \\
\hline $\begin{array}{l}\text { Thijs et al. } \\
2017\end{array}$ & $Y$ & $\mathrm{Y}$ & $\begin{array}{l}\mathrm{Y} \text {, increase } \\
\text { resistance }\end{array}$ & $\begin{array}{l}Y, \text { pain } \\
\text { response, } \\
4 / 10\end{array}$ & $7,2 \times D$ & 15RM & NR & $\begin{array}{l}3 \times 2 \\
(6)\end{array}$ & $\begin{array}{l}15 \\
(180)\end{array}$ & $\begin{array}{l}\text { DSL eccentric } \\
\text { squat, loaded } \\
\text { backpack }\end{array}$ & NR & 7,7 \\
\hline $\begin{array}{l}\text { Horstmann et } \\
\text { al. } 2013\end{array}$ & $Y$ & $\mathrm{Y}$ & $\begin{array}{l}\mathrm{Y} \text {, increase } \\
\text { resistance } \\
+ \text { volume, } \\
\text { based on } \\
\text { fatigue }\end{array}$ & $\begin{array}{l}\mathrm{Y} \text {, increase } \\
\text { resistance }+ \\
\text { volume, } \\
\text { based on } \\
\text { fatigue } \\
\end{array}$ & 7 & 15RM & NR & $3-4$ & 15 & $\begin{array}{l}\text { Modified Alfredson } \\
\text { eccentric heel } \\
\text { raise, knee } \\
\text { straight \& flexed, } \\
\text { loaded backpack }\end{array}$ & NR & 7,7 \\
\hline $\begin{array}{l}\text { Alfredson et } \\
\text { al. } 1998\end{array}$ & $\mathrm{Y}$ & $\mathrm{Y}$ & $\begin{array}{l}\mathrm{Y}, \text { increase } \\
\text { resistance }\end{array}$ & $\begin{array}{l}\mathrm{Y}, \text { pain } \\
\text { response }\end{array}$ & $7,2 \times d$ & 15RM & NR & $\begin{array}{l}3 \times 2 \\
(6)\end{array}$ & $\begin{array}{l}15 \\
(180)\end{array}$ & $\begin{array}{l}\text { Modified Alfredson } \\
\text { eccentric heel } \\
\text { raise, knee } \\
\text { straight \& flexed, } \\
\text { loaded backpack } \\
\text { or weight machine }\end{array}$ & NR & 7,7 \\
\hline $\begin{array}{l}\text { Alvarez et al. } \\
2006\end{array}$ & $Y$ & $\mathrm{Y}$ & $\begin{array}{l}\text { Y, increase } \\
\text { resistance } \\
\text { (elastic } \\
\text { bands) and } \\
\text { volume }\end{array}$ & $\begin{array}{l}\mathrm{Y}, \text { increase } \\
\text { resistance } \\
\text { based on } \\
\text { pain } \\
\text { response + } \\
\text { correct } \\
\text { technique }\end{array}$ & $7,2 \times D$ & 30RM & NR & 3 & 30 & $\begin{array}{l}\text { Isotonic exercise } \\
\text { with elastic bands, } \\
\text { increased } \\
\text { resistance (elastic } \\
\text { bands strength) } 1 . \\
\text { Bilateral heel } \\
\text { raises } 2 \text {. Ankle } \\
\text { plantar flexion with } \\
\text { adduction and }\end{array}$ & Y, diary & 7,9 \\
\hline
\end{tabular}




\begin{tabular}{|c|c|c|c|c|c|c|c|c|c|c|c|c|}
\hline & & & & & & & & & & $\begin{array}{l}\text { Inversion. } \\
\text { 3. Unilateral heel } \\
\text { raises (standing) }\end{array}$ & & \\
\hline $\begin{array}{l}\text { Kearney et } \\
\text { al. } 2013\end{array}$ & $Y$ & $\mathrm{Y}$ & $\begin{array}{l}\text { Y, progress } \\
\text { from DL to } \\
\text { SL with } \\
\text { increased } \\
\text { resistance }\end{array}$ & $\begin{array}{l}\text { Y, pain } \\
\text { response, } \\
\text { progress } \\
\text { from DL to } \\
\text { SL with } \\
\text { increased } \\
\text { load }\end{array}$ & $7,2 \times d$ & 15RM & NR & $\begin{array}{l}3 \times 2 \\
(6)\end{array}$ & $\begin{array}{l}15 \\
(180)\end{array}$ & $\begin{array}{l}\text { Modified Alfredson } \\
\text { eccentric heel } \\
\text { raise, knee } \\
\text { straight \& flexed, } \\
\text { loaded backpack, } \\
\text { DL progressing to } \\
\text { SL }\end{array}$ & NR & 7,7 \\
\hline $\begin{array}{l}\text { Tumilty et al. } \\
2012\end{array}$ & $Y$ & $\mathrm{Y}$ & $\begin{array}{l}\text { Y, increase } \\
\text { resistance }\end{array}$ & $\begin{array}{l}\mathrm{Y}, \text { pain } \\
\text { response }\end{array}$ & $7,2 \times d$ & 15RM & NR & $\begin{array}{l}3 \times 2 \\
(6)\end{array}$ & $\begin{array}{l}15 \\
(180)\end{array}$ & $\begin{array}{l}\text { Modified Alfredson } \\
\text { eccentric heel } \\
\text { raise, knee } \\
\text { straight \& flexed, } \\
\text { loaded backpack }\end{array}$ & NR & 7,7 \\
\hline $\begin{array}{l}\text { Yelland et al. } \\
2011\end{array}$ & $\mathrm{Y}$ & $Y$ & $\begin{array}{l}\mathrm{Y} \text {, increase } \\
\text { resistance }\end{array}$ & $\begin{array}{l}Y, \text { pain } \\
\text { response } \\
4 / 10\end{array}$ & $7,2 \times d$ & 15RM & NR & $\begin{array}{l}3 \times 2 \\
(6)\end{array}$ & $\begin{array}{l}15 \\
(180)\end{array}$ & $\begin{array}{l}\text { Modified Alfredson } \\
\text { eccentric heel } \\
\text { raise, knee } \\
\text { straight \& flexed, } \\
\text { loaded backpack }\end{array}$ & $Y$, diary & 7,9 \\
\hline $\begin{array}{l}\text { McCormack } \\
\text { et al. } 2016\end{array}$ & $\bar{Y}$ & $\mathrm{Y}$ & $\begin{array}{l}\text { Y, increase } \\
\text { resistance }\end{array}$ & NR & $7,2 \times D$ & 15RM & NR & $\begin{array}{l}3 \times 2 \\
(6)\end{array}$ & $\begin{array}{l}15 \\
(180)\end{array}$ & $\begin{array}{l}\text { Modified Alfredson } \\
\text { eccentric heel } \\
\text { raise, knee } \\
\text { straight \& flexed, } \\
\text { loaded backpack }\end{array}$ & NR & 5,5 \\
\hline $\begin{array}{l}\text { Tumilty et al. } \\
2016\end{array}$ & $\mathrm{Y}$ & $Y$ & $\begin{array}{l}\text { Y, increase } \\
\text { resistance }\end{array}$ & $\begin{array}{l}Y, \text { pain } \\
\text { response, } \\
4 / 10\end{array}$ & 2 & 15RM & NR & $\begin{array}{l}3 \times 2 \\
(180)\end{array}$ & $\begin{array}{l}15 \\
(180)\end{array}$ & $\begin{array}{l}\text { Modified Alfredson } \\
\text { eccentric heel } \\
\text { raise, knee } \\
\text { straight \& flexed, } \\
\text { loaded backpack. } \\
\text { 2Xwk V D }\end{array}$ & $\begin{array}{l}\text { Y, diary, } \\
46 \\
\text { returned }\end{array}$ & 7,9 \\
\hline $\begin{array}{l}\text { Cannell et al. } \\
2001\end{array}$ & $Y$ & $Y$ & $\begin{array}{l}\text { Y, increase } \\
\text { resistance } \\
\text { with fixed } \\
\text { loading } \\
\text { protocol \& } \\
\text { external } \\
\text { weight }\end{array}$ & $\begin{array}{l}\text { Y, pain } \\
\text { response }\end{array}$ & 5 & 10-20RM & NR & 3 & $\begin{array}{l}10- \\
20\end{array}$ & $\begin{array}{l}\text { Progressive drop } \\
\text { squats and leg } \\
\text { extension/curl } \\
\text { exercises, fixed } \\
\text { loading protocol, } \\
\text { external weights }\end{array}$ & NR & 8,8 \\
\hline $\begin{array}{l}\text { Jonsson et al. } \\
2005\end{array}$ & $\mathrm{Y}$ & $Y$ & $\begin{array}{l}\text { Y, increase } \\
\text { resistance }\end{array}$ & $\begin{array}{l}\text { Y, self- } \\
\text { acceptable }\end{array}$ & $7,2 \times D$ & 15RM & NR & $\begin{array}{l}3 \times 2 \\
(6)\end{array}$ & $\begin{array}{l}15 \\
(180)\end{array}$ & $\begin{array}{l}\text { Eccentric v } \\
\text { concentric DSL }\end{array}$ & NR & 7,7 \\
\hline
\end{tabular}




\begin{tabular}{|c|c|c|c|c|c|c|c|c|c|c|c|c|}
\hline & & & & $\begin{array}{l}\text { pain } \\
\text { response }\end{array}$ & & & & & & $\begin{array}{l}\text { squat, loaded } \\
\text { backpack }\end{array}$ & & \\
\hline $\begin{array}{l}\text { Mellor et al. } \\
2018\end{array}$ & $Y$ & $\mathrm{Y}$ & $\begin{array}{l}\text { Y, increase } \\
\text { diffciculty/ } \\
\text { intensity } \\
\text { (BORG) }\end{array}$ & $\begin{array}{l}\mathrm{Y} \text {, pain } \\
\text { response } \\
5 / 10, \text { BORG } \\
\text { scale (13-17 } \\
\text { target) }\end{array}$ & 7 & $\begin{array}{l}\text { BORG } \\
(13-17)\end{array}$ & $\begin{array}{l}30 \text { min } \\
x \\
\text { session }\end{array}$ & $1-2$ & $3-15$ & $\begin{array}{l}\text { Comprehensive } \\
\text { progressive } \\
\text { exercise program } \\
\text { targeting hip } \\
\text { muscles, } \\
\text { monitored by pain } \\
\text { response and } \\
\text { BORG scale. } \\
\text { External load NR. } \\
\text { Spring resistance } \\
\text { for hip abduction }\end{array}$ & $\begin{array}{l}\text { Y, diary, } \\
80 \%\end{array}$ & 8,10 \\
\hline $\begin{array}{l}\text { Kedia et al. } \\
2014\end{array}$ & $Y$ & $Y$ & $\begin{array}{l}Y \text {, increase } \\
\text { resistance }\end{array}$ & $\begin{array}{l}\text { Y, exercise } \\
\text { difficultly, } \\
\text { increase } \\
\text { resistance }\end{array}$ & $7,2 \times d$ & $15 R M$ & NR & $\begin{array}{l}3 \times 2 \\
(6)\end{array}$ & $\begin{array}{l}15 \\
(180)\end{array}$ & $\begin{array}{l}\text { Modified Alfredson } \\
\text { eccentric heel } \\
\text { raise, knee } \\
\text { straight \& flexed, } \\
\text { loaded backpack }\end{array}$ & $\begin{array}{l}\text { Y, diary, } \\
\text { NR }\end{array}$ & 7,8 \\
\hline $\begin{array}{l}\text { Herrington et } \\
\text { al. } 2007\end{array}$ & $\mathrm{Y}$ & $\mathrm{Y}$ & $\begin{array}{l}\mathrm{Y} \text {, increase } \\
\text { speed and } \\
\text { resistance }\end{array}$ & $\begin{array}{l}\text { Y, increase } \\
\text { speed and } \\
\text { resistance } \\
\text { based on } \\
\text { pain } \\
\text { response }\end{array}$ & $7,2 \times D$ & 15RM & NR & $\begin{array}{l}3 \times 2 \\
(6)\end{array}$ & $\begin{array}{l}15 \\
(180)\end{array}$ & $\begin{array}{l}\text { Modified Alfredson } \\
\text { eccentric heel } \\
\text { raise, knee } \\
\text { straight \& flexed, } \\
\text { loaded backpack }\end{array}$ & $\begin{array}{l}\text { Y, diary, } \\
\text { NR }\end{array}$ & 7,8 \\
\hline $\begin{array}{l}\text { Houck et al. } \\
2015\end{array}$ & $Y$ & $Y$ & $\begin{array}{l}\mathrm{Y} \text {, increase } \\
\text { resistance } \\
\text { - elastic } \\
\text { bands } \\
\text { strength }\end{array}$ & $\begin{array}{l}Y \text {, increase } \\
\text { resistance } \\
\text { based on } \\
\text { pain } \\
\text { response \& } \\
\text { Ex technique }\end{array}$ & $7,2 \times D$ & 30RM & $\begin{array}{l}30 \text { min } \\
x \\
\text { session }\end{array}$ & $\begin{array}{l}3 \times 2 \\
(6)\end{array}$ & $\begin{array}{l}30 \times \\
3 \times 3 \\
(180)\end{array}$ & $\begin{array}{l}\text { Bilateral \& } \\
\text { unilateral heel } \\
\text { raises, ankle } \\
\text { plantarflexion with } \\
\text { adduction \& } \\
\text { inversion. } \\
\text { Resistance bands }\end{array}$ & Y, diary & 7,9 \\
\hline $\begin{array}{l}\text { Dimitrios et } \\
\text { al. } 2012\end{array}$ & $Y$ & $Y$ & $\begin{array}{l}\mathrm{Y} \text {, increase } \\
\text { resistance } \\
\text { with } \\
\text { handheld } \\
\text { weights }\end{array}$ & $\begin{array}{l}\mathrm{Y}, \text { pain } \\
\text { response }\end{array}$ & 5 & 15RM & NR & 3 & 15 & $\begin{array}{l}\text { Eccentric DSL } \\
\text { squat, handheld } \\
\text { weights }\end{array}$ & $\begin{array}{l}\text { Y, diary, } \\
\text { NR }\end{array}$ & 7,8 \\
\hline $\begin{array}{l}\text { Petersen et } \\
\text { al. } 2007\end{array}$ & $\mathrm{Y}$ & $Y$ & $\begin{array}{l}\mathrm{Y} \text {, increase } \\
\text { resistance }\end{array}$ & $\begin{array}{l}\mathrm{Y}, \text { pain } \\
\text { response }\end{array}$ & $7,3 \times D$ & 15RM & NR & $\begin{array}{l}3 \times 3 \\
(9)\end{array}$ & $\begin{array}{l}15 \\
(270)\end{array}$ & $\begin{array}{l}\text { Modified Alfredson } \\
\text { eccentric heel } \\
\text { raise, knee }\end{array}$ & $\begin{array}{l}\text { Y, diary, } \\
\text { NR }\end{array}$ & 7,8 \\
\hline
\end{tabular}




\begin{tabular}{|c|c|c|c|c|c|c|c|c|c|c|c|c|}
\hline & & & & & & & & & & $\begin{array}{l}\text { straight \& flexed, } \\
\text { loaded backpack }\end{array}$ & & \\
\hline $\begin{array}{l}\text { Steunebrink } \\
\text { et al. } 2013\end{array}$ & $Y$ & $\mathrm{Y}$ & $\begin{array}{l}Y, \text { increase } \\
\text { resistance } \\
(5 \mathrm{~kg} \text { inc) }\end{array}$ & $\begin{array}{l}Y, \text { pain } \\
\text { response, } \\
3 / 10= \\
\text { increase load }\end{array}$ & $7,2 \times d$ & $15 R M$ & NR & $\begin{array}{l}3 \times 2 \\
(6)\end{array}$ & $\begin{array}{l}15 \\
(180)\end{array}$ & $\begin{array}{l}\text { Modified Alfredson } \\
\text { - Eccentric DSL } \\
\text { squat }\end{array}$ & NR & 8,8 \\
\hline $\begin{array}{l}\text { Rompe et al. } \\
2009\end{array}$ & $Y$ & $Y$ & $\begin{array}{l}\mathrm{Y} \text {, increase } \\
\text { resistance } \\
(5 \mathrm{~kg} \text { inc) }\end{array}$ & $\begin{array}{l}\mathrm{Y}, \text { pain } \\
\text { response }\end{array}$ & $7,2 \times D$ & 15RM & NR & $\begin{array}{l}3 \times 2 \\
(6)\end{array}$ & $\begin{array}{l}10- \\
15 \\
(180)\end{array}$ & $\begin{array}{l}\text { Modified Alfredson } \\
\text { eccentric heel } \\
\text { raise, knee } \\
\text { straight \& flexed, } \\
\text { loaded backpack }\end{array}$ & NR & 8,8 \\
\hline $\begin{array}{l}\text { Young et al. } \\
2005\end{array}$ & $Y$ & $\mathrm{Y}$ & $\begin{array}{l}\mathrm{Y} \text {, increase } \\
\text { speed, then } \\
\text { resistance } \\
(5 \mathrm{~kg} \text { inc) }\end{array}$ & $\begin{array}{l}\text { Y, pain } \\
\text { response }\end{array}$ & $7.2 \times d$ & 15RM & NR & $\begin{array}{l}3 \times 2 \\
(6)\end{array}$ & $\begin{array}{l}15 \\
(180)\end{array}$ & $\begin{array}{l}\text { Modified Alfredson } \\
\text { DSL squat, loaded } \\
\text { backpack }\end{array}$ & Y, diary & 8,10 \\
\hline $\begin{array}{l}\text { De Jonge et } \\
\text { al. } 2010\end{array}$ & $Y$ & $\mathrm{Y}$ & $\begin{array}{l}\mathrm{Y}, \text { increase } \\
\text { resistance }\end{array}$ & $\begin{array}{l}\mathrm{Y}, \text { pain } \\
\text { response }\end{array}$ & $7,2 \times d$ & 15RM & NR & $\begin{array}{l}3 \times 2 \\
(6)\end{array}$ & $\begin{array}{l}15 \\
(180)\end{array}$ & $\begin{array}{l}\text { Modified Alfredson } \\
\text { eccentric heel } \\
\text { raise, knee } \\
\text { straight \& flexed, } \\
\text { loaded backpack } \\
\text { or weight machine }\end{array}$ & $\mathrm{Y}$, diary & 7,9 \\
\hline $\begin{array}{l}\text { Praet et al. } \\
2019\end{array}$ & $Y$ & $Y$ & $\begin{array}{l}\text { Y, increase } \\
\text { speed, then } \\
\text { resistance } \\
\text { (5kg inc } \\
\text { until max } \\
60 \mathrm{~kg})\end{array}$ & $\begin{array}{l}\mathrm{Y}, \text { pain } \\
\text { response }\end{array}$ & $7,2 \times D$ & 15RM & NR & $\begin{array}{l}3 \times 2 \\
(6)\end{array}$ & $\begin{array}{l}15 \\
(180)\end{array}$ & $\begin{array}{l}\text { Modified Alfredson } \\
\text { eccentric heel } \\
\text { raise, knee } \\
\text { straight \& flexed, } \\
\text { loaded backpack }\end{array}$ & $\begin{array}{l}\text { Y, diary, } \\
\text { NR }\end{array}$ & 8,9 \\
\hline $\begin{array}{l}\text { Rathleff et al. } \\
2015\end{array}$ & $\mathrm{Y}$ & $Y$ & $\begin{array}{l}\text { Y, increase } \\
\text { resistance }\end{array}$ & NR & 3 & 12-8RM & NR & $3-5$ & $12-8$ & $\begin{array}{l}\text { Heel raise on step } \\
\text { with toes } \\
\text { maximally } \\
\text { dorsiflexed on } \\
\text { towel }\end{array}$ & NR & 5,5 \\
\hline $\begin{array}{l}\text { Knobloch et } \\
\text { al. } 2008\end{array}$ & $Y$ & NR & NR & NR & $7,2 \times D$ & $15 R M$ & NR & $\begin{array}{l}3 \times 2 \\
(6)\end{array}$ & $\begin{array}{l}15 \\
(180)\end{array}$ & $\begin{array}{l}\text { Modified Alfredson } \\
\text { eccentric heel } \\
\text { raise, knee } \\
\text { straight \& flexed, }\end{array}$ & NR & 2,2 \\
\hline $\begin{array}{l}\text { Wheeler et } \\
\text { al. } 2017\end{array}$ & $Y$ & NR & NR & NR & NR & NR & NR & NR & NR & $\begin{array}{l}\text { stretching, calf \& } \\
\text { foot muscle } \\
\text { strengthening and } \\
\text { balance exercises. }\end{array}$ & NR & 2,2 \\
\hline
\end{tabular}


